1

2

3

4

5

6

7

8

9

10

11

12

13

14

15

Declaration of interest: none

\title{
A novel multi-objective decision support method for ship energy systems synthesis to enhance sustainability
}

Nikoletta L. Trivyza ${ }^{\mathrm{a}, *}$, Athanasios Rentizelas ${ }^{\mathrm{a}}$, Gerasimos Theotokatos ${ }^{\mathrm{b}}$

${ }^{a}$ Department of Design Manufacture and Engineering Management, University of Strathclyde, 75 Montrose Street, G1 1XJ, Glasgow, UK

${ }^{b}$ Maritime Safety Research Centre, Department of Naval Architecture, Ocean and Marine Engineering,

University of Strathclyde, 100 Montrose Street, G4 OLZ, Glasgow, UK

"Corresponding Author. Email address: nikoletta.trivyza@ strath.ac.uk

\section{Abstract}

The shipping industry has been facing great pressure to become more sustainable, emanating from the increasingly stringent environmental regulations, fuel prices volatility and societal needs. As a result, a variety of established technologies have been developed aiming to improve the environmental and economic performance of the modern ship energy systems, however leading to additional challenges for the technology selection during the design process. This study introduces an innovative method that integrates the economic and environmental aspects of sustainability to support decisions on the synthesis of the modern ship energy systems. The method includes a simulation model for predicting the energy systems performance during the ship lifetime. A genetic algorithm, NSGA-II, is employed to solve the multi-objective combinatorial optimisation problem of selecting the integrated ship energy systems configuration. The derived results are visualised to reveal the Pareto front and the trade-offs among the objectives. The method is novel in supporting the synthesis of the integrated ship energy systems, as it includes both environmental and economic objectives, as well as evaluates the performance of the systems over an expected operational profile. The developed method is implemented for the case study of an Aframax oil tanker and the derived results analysis indicates that the ship energy systems sustainability can be improved by adopting LNG fuel and dual fuel engines technology, as well as by introducing other emerging technologies like fuel cells and carbon capture, although the latter are associated with a high cost. It is concluded that the inclusion of both environmental and economic objectives highlights the trade-offs between more environmentally friendly or cost efficient configurations, thus supporting the multi-objective decision-making process. 
Keywords: ship energy systems synthesis, multi-objective optimisation, operational profile, Pareto front, decision support, environmental and economic sustainability

\section{Introduction}

In the past few years, there has been a growing interest to enhance the sustainability of shipping operations. Shipping has a very important role in the global economy, with $90 \%$ of the global trade being transported by ships [1]. Although ship transportation is considered one of the most environmentally friendly modes of transport [2], great attention has been placed on improving the environmental sustainability due to the magnitude of the shipping operations [3,4]. Global shipping accounts for approximately $3 \%$ of global $\mathrm{CO}_{2}$ emissions [5] and in the case where international shipping was a country it would be ranked the sixth carbon emissions producer [6]. With regard to other anthropogenic emissions, 4-9\% of global SOx and 15\% of NOx emissions are attributed to shipping operations [7] and their further increase of around 40-50\% is anticipated from 2000 to 2020 [8]. Finally, shipping operations have a major impact on the fossil fuel depletion as more than 350 million tonnes of fossil fuels per year are consumed [9], corresponding to 5\% of the total transportation sector energy consumption [10].

Due to the significant environmental impact of the shipping operations, the environmental regulations imposed in the shipping industry by the International Maritime Organisation (IMO) as well as national authorities have become more stringent. Regulations have been implemented to set limits on the emissions of NOx and SOx from ship engines and the intention is to become even stricter in the future [11]. IMO introduced the first maritime energy efficiency regulation in 2011 [11], which is highly related to the reduction of the $\mathrm{CO}_{2}$ gas emissions. According to this regulation, all new vessels have to comply with the Energy Efficiency Design Index (EEDI) [12] and all new and existing ships need to have a specific Ship Energy Efficiency Management Plan (SEEMP) [13]. However, these measures could not manage to reach the global targets set for $\mathrm{CO}_{2}$ emissions [14]. In consequence, a Monitoring, Reporting and Verification (MRV) system for carbon dioxide emissions was introduced by the EU [15]. Furthermore, it is discussed to introduce shipping operations into the European Emission Trading Market Scheme (EU ETS) for $\mathrm{CO}_{2}$ emissions as well as to tax the carbon emissions [16], in a manner similar to land-based power plants. As a result of this changing regulatory landscape, in order to achieve compliance with the existing and future regulations, ship-owners will be necessitated to retrofit their ship energy systems with emission reduction technologies, to use more expensive low-sulphur fuel, or to employ waste heat recovery technologies, thus increasing the shipping expenses. 
Therefore, the shipping industry is required to pursue more sustainable operations, due to the environmental regulatory pressure, as well as the fuel prices volatility and the pressure from society. To satisfy the regulatory requirements and fulfil the goals for sustainability, a shift to new more environmentally efficient technologies and greener fuels is required [17]. A variety of existing and emerging technologies can be used to that purpose, which can though increase the complexity of the modern ship energy systems due to the large number of potential combinations and alternative technologies and as a result, render the energy systems selection process even more challenging. Thus, this work proposes a method to support decisions for the selection of ship energy systems, which aims to improve the environmental and economic sustainability, addresses the multi-component integrated ship energy systems selection challenge and takes into consideration the operational and regulatory requirements.

\subsection{Background}

Ship energy systems are employed for covering the ship requirements for energy of various forms. The major ship energy producers include the propulsion system and the electric and thermal auxiliary machinery that are responsible for completing the ship mission [18]. The selection of the energy systems components is defined as the synthesis process. More specifically, the generation of a number of possible alternative systems and the selection among them according to their performance analysis is part of the synthesis process [19]. Several studies were published to support decisions on the selection of specific ship technologies, as discussed in the following paragraphs.

An extended number of studies focused on alternative emission reduction solutions to reduce anthropogenic emissions from ships. In [20] and [21] the authors explored the economic impact and possibilities of SOx emission reduction technologies. The selection of black carbon reduction technologies was addressed in [22]. Other researchers investigated the combination of NOx and SOx emission abatement technologies, regarding their economic impact [23-25], whereas the simultaneous usage of $\mathrm{NOx}, \mathrm{SOx}$ and $\mathrm{CO}_{2}$ abatement technologies were investigated in [26]. Classification societies have compared and discussed the performance of different alternatives in order to comply with the air pollution regulations for NOx and SOx emissions [27] or to reduce the carbon footprint [28]. It is evident that there is a large number of emission reduction alternatives and several studies focused on assessing the performance of these alternatives regarding their economic impact. 
The waste heat recovery (WHR) system was also investigated as an alternative to reduce emissions and improve ship power plant energy efficiency. In a variety of studies, the performance of WHR systems regarding economic and efficiency criteria was evaluated. Different WHR systems and their potential were reviewed in [29]. Several authors focused on the evaluation of WHR systems applied to specific ship types; a technoeconomic evaluation of WHR system was performed in [30,31], whereas the energy and exergy efficiency of a WHR was evaluated in [32]. The techno-economic performance of an Organic Rankine Cycle system (ORC) was investigated in [33-35]. Simulating the ORC performance in order to optimise the energy efficiency was reported in [36]. Studies on the optimisation of an ORC in order to improve the system efficiency were reported in [37-39].

The evaluation of alternative propulsion systems and their integration with emission reduction or WHR technologies, in order to reduce the environmental and economic impact of ships, have been extensively discussed. The introduction of the LNG fuel for propulsion, in order to reduce $\mathrm{CO}_{2}$ emissions and operational costs, has been addressed in [40]. The performance of a two-stroke dual fuel engine with respect of the NOx and $\mathrm{CO}_{2}$ emissions reduction was investigated in [41]. The energy and exergy analysis of a turbo-generator and steam turbine of an LNG carrier in order to improve the systems energy efficiency was discussed in [42]. The technical and economic optimisation of the integrated power plant configuration of an LNG carrier that includes a WHR, taking into account the weather conditions throughout the ship voyage was presented in [43]. The techno-economic performance of alternative propulsion systems for Ferries and RoRo ships including dual fuel engines and Selective Catalytic Reduction (SCR) was investigated in [44]. Regarding the carbon footprint reduction, alternative propulsion systems for a tanker, including dual fuel engines and a WHR system were examined in [45]. In [46], the optimisation of a cruise ship propulsion system with a gas turbine and heat recovery for steam and electric production was addressed. The economic optimisation of emission control technologies simultaneously with the selection of the main engine was also analysed in [47]. Proposing more innovative propulsion systems, an optimisation of the fuel consumption and the installation weight of a hybrid propulsion system was performed in [48], the load allocation of a hybrid propulsion system on a cruise ship was optimised in [49], whereas the economic optimisation of an electric propulsion system was addressed in [50].

Finally, innovative technologies that provide electric and thermal auxiliary power leading to an improved environmental impact have been investigated. The possibility of employing fuel cell systems as an auxiliary 
thermal storage on board ships was discussed in [54], whereas the optimal photovoltaic system and the analysis of solar energy on board ships were addressed in [55] and [56], respectively.

Several studies aimed at improving the environmental impact of the ship energy systems by introducing emission reduction technologies, energy efficient technologies, alternative fuels and emerging auxiliary technologies. However, there is a lack in a systematic way of including the environmental objectives in the optimisation process along with the economic objectives. Improving the sustainable performance of energy systems requires adopting an approach that integrates the techno-economic and environmental assessment [57,58]. Thus, the existing studies on ship energy systems synthesis lack in methods that integrate both aspects of sustainability and therefore, ultimately fail to improve simultaneously both the environmental and economic sustainability performance of ship energy systems.

The ship energy systems include a large number of components, which increase their complexity. In the existing literature, studies have focused on the assessment of one or two specific components, a specific predefined propulsion system or in other cases performed a comparative assessment of a limited number of potential alternatives. However, an approach that addresses the integrated ship energy systems is required due to the importance of the interconnections among the various sub-systems, the considerable number of components and their non-linear interrelations [59]. Thus, a shift from component level to a more integrated approach has to be adopted in order to address the system complexity, which is also recognised as a necessary step for sustainable design [60]. In addition, since the systems are highly interactive, improving the performance of one subsystem may lead to deteriorating another subsystem performance. It can therefore be inferred that an integrated approach is required for the optimal synthesis and design of the ship energy systems.

According to the traditional ship energy systems synthesis techniques, the machinery is selected according to previous experience or empirical criteria [46] aiming to address only one design point based on the nominal power; thus, disregarding the variable operational profile and the off-design conditions that characterise the reallife operation of ships. However, the ship during her lifetime follows a varying operational profile [61], usually far away from the design point. In a specific case examined in the literature, even though the design speed of the vessel was 21 knots, the ship-board measurements showed that the ship did not even reach 16 knots during her operation [34]. In general, the ship operational profile differs significantly from the design points [62]. This leads to underuse of the systems and as a consequence, to higher costs, potential reliability and safety issues [63], as well as less efficient operation. It is proposed that in order to accurately assess the performance of a 
system in the design phase, the expected operational profile of the ship has to be employed [64]. Therefore, it is significant to incorporate the expected operational profile in the synthesis process of the ship energy systems, in order to accurately assess the actual performance of the systems.

Based on the preceding discussion, two main gaps were identified in the literature. Firstly optimising the ship energy systems synthesis considering the environmental and economic aspects of sustainability simultaneously with the lifetime varying operational profile of ship systems and secondly, the lack of a method capable of handling the generic energy ship systems synthesis problem challenges due to the variety of available technologies and their interconnections. This work aims at addressing these gaps by proposing a novel method to support decisions for the ship energy systems synthesis. To this purpose, a multi-objective method is proposed that simultaneously considers and optimises environmental and economic objectives. In addition, a simulation model of the integrated ship energy systems performance including all major systems is developed and the evaluation of the ship energy systems is performed based on an expected operational profile.

The rest of the paper is organised as follows. The method developed in this work to support decisions for ship energy systems synthesis is introduced in Section 2, which is subsequently applied to a case study, in order to demonstrate its applicability in Section 3. The investigated case study results from the application are discussed in Section 4 and the concluding remarks are presented in Section 5.

\section{Method for supporting decisions on ship energy systems synthesis}

A method is developed that supports the decision maker to make an informed decision regarding the integrated ship energy systems synthesis. The proposed method includes a simulation tool and a multi-objective optimisation algorithm and is illustrated in the flowchart shown in Figure 1. The ship energy systems performance is estimated through mathematical modelling and is subsequently employed to obtain the specific parameters required for the calculation of the environmental and economic indicators, leading to the sustainability assessment of the investigated ship energy systems. A multi-objective optimisation algorithm is finally used to simultaneously address the environmental and economic objectives providing a Pareto front of optimum solutions that allows understanding the trade-offs between the objectives. 


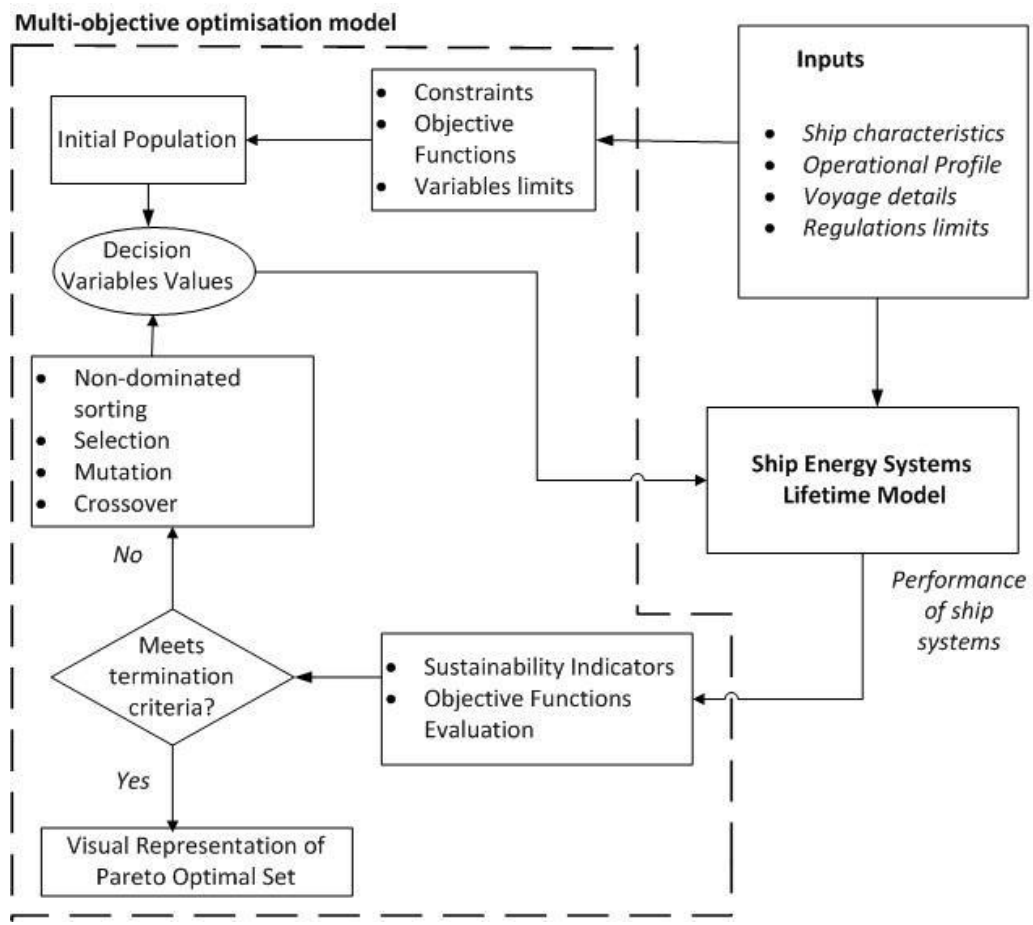

Based on the input and the variables ranges, the initial population is generated by the optimisation algorithm. Subsequently, according to the decision variable values and the provided input parameters the simulation model estimates the ship energy systems lifetime performance and uses it to calculate the indicators for the assessment of the ship energy systems environmental and economic sustainability. These indicators form the objective functions that are then evaluated. Following the evaluation of the objective functions, the individual solutions are ranked and the selection, crossover and mutation operators are applied. The process is repeated until the termination criteria are met and the Pareto front is visualised.

The optimisation requires a number of input parameters, regarding the ship characteristics (ship type and deadweight), as well as the voyage details including the period of time the vessel sails in Emission Control Areas (ECA) and the expected operating profile. The limits of the regulated emissions $[65,66]$ and the minimum propulsion power requirement [67] are calculated according to IMO regulations.

The inclusion of the operational profile is necessary in order to simulate the lifetime performance of the ship energy systems. The operational profile represents the ship mechanical, thermal, and electric power demands throughout the vessel lifetime. It is described through distinct operational phases, as have been captured from data observed on board. These operational phases are expressed through the power needed and 

computational model in Matlab.

\subsection{Mathematical modelling and simulation of ship energy systems}

Appropriate models were developed to simulate the performance and the behaviour of the investigated system. Empirical models, also called black box, are often used since they do not require knowledge of the system physical laws and can predict the output using a limited number of input parameters [59]. The empirical models approach is selected as the most appropriate in this study due to the following reasons:

192

- Only high-level details are needed, because a large number of technologies is modelled, including novel technologies that are not yet established and their exact performance is not known.

- There is interest only on the gaseous emissions and the cost of the systems.

- An exact representation of reality is not needed for the assessment of energy systems at the design stage.

- Only steady-state conditions are studied.

A ship is considered a complex system consisting of several subsystems that serve a function. Each subsystem consists of components that have a different performance and are highly interconnected [59]. Applying a systems engineering approach to model the complex ship energy systems allows to tackle the complexity and address the integrated system including the involved interactions [68]. Systems engineering encompasses a hierarchical approach to deal with complexity, by decomposing the whole system into subsystems [69].

The systems engineering approach is adopted in this work in order to develop the simulation model and it is presented in Figure 2. The ship energy systems are decomposed into five sub-systems, which include the three main energy sub-systems (main engine sub-system, electric and thermal auxiliary sub-systems), the emission reduction technologies and the energy efficiency technologies sub-systems. Each sub-system performance is modelled separately while considering the sub-systems interactions. The interactions between the sub-systems are displayed through the dashed lines in Figure 2, where the input and output parameters for the sub-systems are depicted through arrows. 


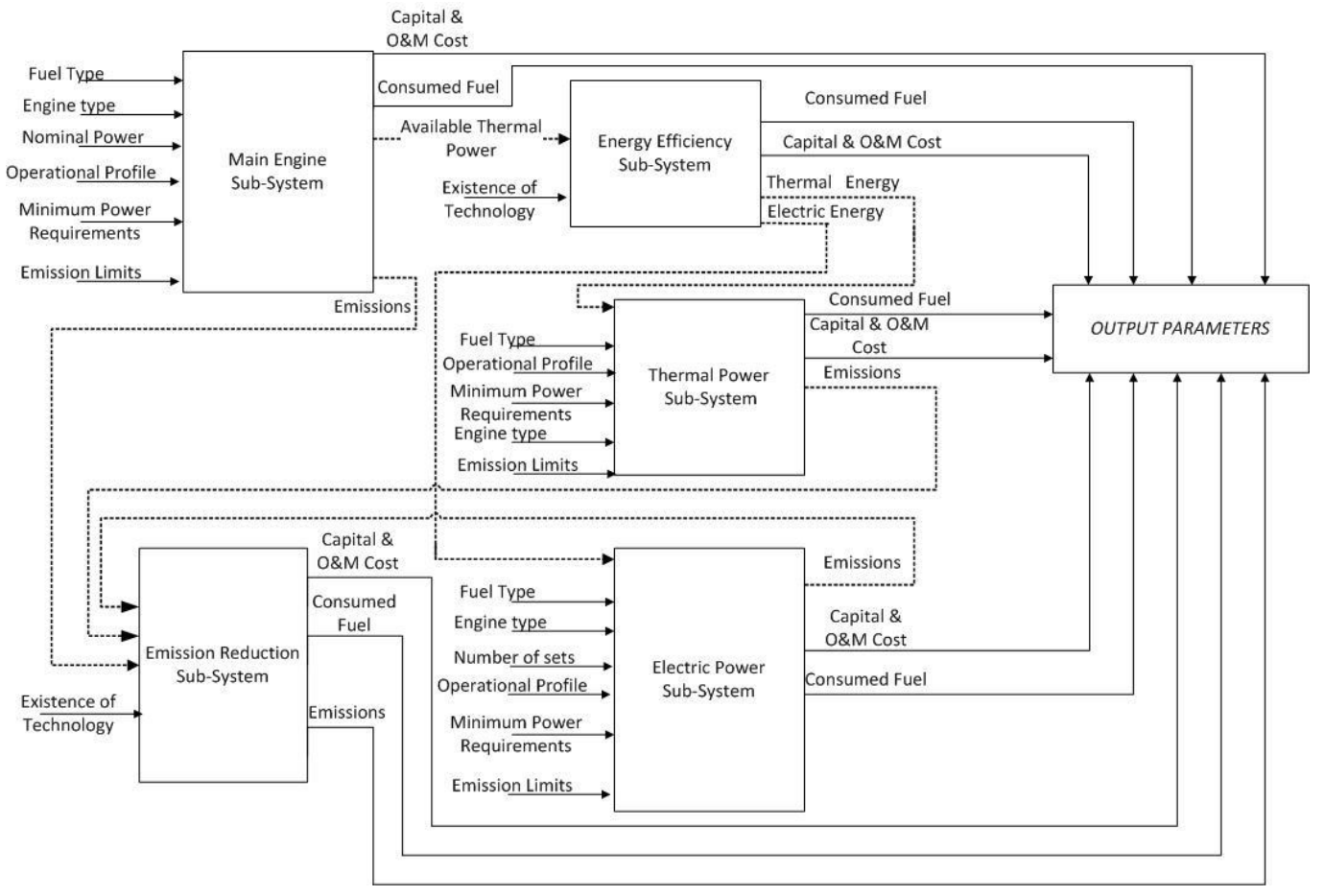

The specific parameters of the sub-systems performance that have an impact on the calculation of the indicators are modelled in this work. For the propulsion subsystem, the engines performance equations are based on multiple regression performed on data identified in the Project Guides of two-stroke engines manufacturers [70] and are displayed in Tables 1 and 2.

Table 1: Diesel engine performance

\begin{tabular}{ll}
\hline Performance & Equation \\
\hline Specific Fuel consumption $(\mathrm{g} / \mathrm{kWh})$ & $s f c=\left(\mathrm{a}_{1}+\mathrm{a}_{2} P_{n}\right) L+\mathrm{a}_{3}+\mathrm{a}_{4} P_{n}$ \\
\hline Nominal speed at MCR $(\mathrm{r} / \mathrm{min})$ & $r p m=a_{5}+a_{6} P_{n}$ \\
\hline Exhaust gas mass flow rate $(\mathrm{kg} / \mathrm{s})$ & $e g a=\left(\mathrm{a}_{7}+\mathrm{a}_{8} P_{n}\right) L+\left(\mathrm{a}_{9} P_{n}+\mathrm{a}_{10}\right)$ \\
\hline Exhaust gas temperature $\left({ }^{\circ} \mathrm{C}\right)$ & egt $=\left(\mathrm{a}_{11}+\mathrm{a}_{12} P_{n}\right) \mathrm{L}^{3}+\left(\mathrm{a}_{13}+\mathrm{a}_{14} P_{n}\right) \mathrm{L}^{2}+\left(\mathrm{a}_{15}+\mathrm{a}_{16} P_{n}\right) L+\mathrm{a}_{17}+\mathrm{a}_{18} P_{n}$
\end{tabular}

218 The engine performance parameters ( $\mathrm{sfc}$, ega, egt, rpm) were modelled as functions of the nominal power $\mathrm{P}_{\mathrm{n}}$

$219(\mathrm{~kW})$ at Maximum Continuous Rating (MCR) and the load L which is derived from the operational profile for 220 the propulsion power demand. The analysis was conducted by employing polynomial regression, using the least square fitting method. The R-squared values for all the performed regressions were estimated to be above $80 \%$, thus indicating sufficient regression accuracy. 
Table 2: Dual fuel Gas Injected (GI) (in gas mode) engine performance

\begin{tabular}{ll}
\hline Performance & Equation \\
\hline Specific Pilot fuel consumption $(\mathrm{g} / \mathrm{kWh})$ & $s p o c=\left(b_{1} P_{n}{ }^{2}+\mathrm{b}_{2} P_{n}+b_{3}\right) L^{\left(\mathrm{b}_{4} P_{n}{ }^{2}+\mathrm{b}_{5} P_{n}{ }^{b_{6}}\right)}$ \\
\hline Specific Gas consumption $(\mathrm{g} / \mathrm{kWh})$ & $s g c=\left(\mathrm{b}_{7}+\mathrm{b}_{8} P_{n}\right) L^{2}-\left(\mathrm{b}_{9}+\mathrm{b}_{10} P_{n}\right) L+\mathrm{b}_{11}+\mathrm{b}_{12} P_{n}$ \\
\hline Nominal speed at MCR $(\mathrm{r} / \mathrm{min})$ & $r p m=b_{13}+b_{14} P_{n}$ \\
\hline Exhaust gas mass flow rate $(\mathrm{kg} / \mathrm{s})$ & $e g a=\left(\mathrm{b}_{15}+\mathrm{b}_{16} P_{n}\right) L+\left(\mathrm{b}_{17} P_{n}+\mathrm{b}_{18}\right)$ \\
\hline Exhaust gas temperature $\left({ }^{\circ} \mathrm{C}\right)$ & $e g t=\left(\mathrm{b}_{19}+\mathrm{b}_{20} P_{n}\right) \mathrm{L}^{2}+\left(\mathrm{b}_{21} P_{n}+\mathrm{b}_{22}\right) \mathrm{L}+\mathrm{b}_{23}+\mathrm{b}_{24} P_{n}$
\end{tabular}

The calculations for superheated and saturated steam produced from the waste heat recovered from the main engine and the total electric energy produced from the generator, are modelled for a single pressure boiler and a turbo-generator [71]. The equations for the efficiency of the generators and the load correction factors are estimated according to data reported in [71]. The urea consumption of the Selective Catalytic Reactor (SCR) is modelled as a function of the engine power and the amount of NOx emissions reduction according to [72]. The carbon capture system $\mathrm{CO}_{2}$ reduction capability and the required caustic soda consumption are modelled according to [73].

The modelling of the performance of diesel generators is conducted by using data from the engine manufacturers project guides; in specific, data for four-stroke diesel engines with Tier II compliance were derived from MAN Diesel \& Turbo Project Guides [74], whereas data for dual fuel generator sets with Tier III compliance were taken from Wärtsilä Project Guides [75]. The modelling of the fuel consumption of fuel cells was conducted according to [52], whereas the fuel consumption of the thermal boiler is estimated by using the Equation (1), based on the produced saturated steam thermal power.

$$
\dot{m}_{f, t h}=\frac{\dot{m}_{s} \Delta h}{\eta_{t h} L H V}
$$

\subsection{Sustainability assessment indicators}

The environmental and economic sustainability of the ship energy systems are both addressed in this work; however, the social dimension of sustainability is not included herein due to the limitations of existing social assessment methods for marine technologies and the subjectivity introduced from the quantification of the social impact [76]. In addition, lack of knowledge on developing relationships between the social criteria and the economic and environmental ones exists [77], which may lead to inconsistent results. Indicators that represent the major categories of the shipping operations impact have been used in order to compare the alternative systems in terms of the environmental and economic sustainability assessment. 


\subsubsection{Environmental assessment indicators}

247 The indicators selected to represent the environmental impact of the ship energy systems are expressed in terms of gaseous emissions during the ship lifetime. The chosen approach has been widely used in the literature in order to express the environmental impact of a vessel power plant $[78,79]$ since gaseous emissions indicators representatively reflect the environmental impact of the ship energy systems [80] and a variety of methods is available to estimate them [81]. Is should be noted that only the gaseous emissions due to the vessel operational phase are addressed in this work. The operational phase is by far the most impactful for the whole ship life cycle in respect to energy consumption [82] and to gaseous emissions, as more than 95\% of the life cycle SOx, NOx and $\mathrm{CO}_{2}$ emissions [83] are related to the ship operational phase. A full life cycle environmental assessment analysis is beyond the scope of this work; therefore, the building and decommissioning phases are not considered herein from an environmental impact perspective.

In this study, the approach employed to quantify the emissions from the ship energy systems is through the use of Emissions Factors (EF), that have been successfully employed in $[81,84-86]$ in order to estimate the emissions. Emission factors depend on the pollutant, the engine type, the fuel and the engine operational activity. Emission factors are developed from machinery tests or combustion calculations and are either energy based $\left(\mathrm{EF}_{\mathrm{eb}}\right)$ (measured in $\mathrm{g} / \mathrm{kWh}$ ) or fuel consumption based $\left(\mathrm{EF}_{\mathrm{fb}}\right)$ (measured in $\mathrm{g}$ pollutant/g fuel) [87]. Employing EF for the emissions calculation is an approach that emphasises on the differences among the various engine types and fuels, thus $\mathrm{EF}$ are convenient for the comparison of the ship machinery environmental impact. For energy-based pollutants, like NOx emissions, the annual emissions emitted per sub-system are calculated according to Equation (2), whilst for the fuel consumption based pollutants, like $\mathrm{SOx}$ and $\mathrm{CO}_{2}$, the emissions are calculated according to Equation (3).

$$
\begin{gathered}
E_{s s, p}=\sum_{i=1}^{I} P_{i} h_{i} E F_{e b(p, s s)} \\
E_{s s, p}=\sum_{i=1}^{I} s f c_{i} P_{i} h_{i} E F_{f b}(p, f)
\end{gathered}
$$




\subsubsection{Economic assessment indicators}

For the representation of the economic aspect of sustainability, the Life Cycle Cost (LCC) indicator is employed. According to [77], the life cycle costs should be considered when making a financial decision, since apart from the capital cost, operational cost is a considerable cost element. Particularly for the shipping operations, techno-economic studies on the annualised machinery cost of various power plant alternatives demonstrated that the operational costs are more than three times higher than the capital costs [44]. In addition, similar conclusions were derived in [50], where it is stated that the fuel cost for a 20 years investment period, is responsible for $91 \%$ of the total lifetime expenditure. Thus, the Life Cycle Cost is a useful tool to assess the economic impact of the ship energy systems, as it is suitable for detailed financial analysis [3] and it is helpful when making sustainable investment decisions [77].

LCC includes the capital and the operational cost (consisting of maintenance, fuel, spare parts cost and consumables for the various subsystems and technologies) over the ship economic life. The yearly operational costs are calculated, then brought to present value with an appropriate discounting function and added to the capital cost in order to calculate the life cycle cost indicator according to Equation (4).

$$
L C C=C A P E X+\sum_{k=1}^{Y} \frac{O P E X_{k}}{(1+i r)^{k}}
$$

It is evident from Equations (2)-(4) that specific parameters of the performance of the systems are necessary for the indicators calculation.

\subsection{Multi-objective optimisation of ship energy systems synthesis}

The optimisation of the ship energy systems is described in this section; the optimisation uses the simulation model of the systems (Section 2.1) to estimate the environmental and economic sustainability indicator values presented in Section 2.2. These indicators form the objective functions presented herein.

The objectives of this multi-objective optimisation problem, as derived from the aim of this study, are to minimise simultaneously the life cycle cost of the ship energy systems represented by Equation (5) and the various gaseous emissions represented by Equation (6) throughout the vessel lifetime for an expected operational profile and considering constraints set by the regulatory requirements. 


$$
\begin{gathered}
\min F 1_{(p s, e s, t s, e e, e r)}=C A P E X+\sum_{k=1}^{Y} \frac{O P E X_{k}}{(1+i r)^{k}} \\
\min F 2 p_{(p s, e s, t s, e e, e r)}=\sum_{k=1}^{Y}\left(E_{m e, p}+E_{a e, p}+E_{t h, p}-\sum_{y=1}^{o_{e r, p}}\left(b_{p, y} E_{p, y}\right)\right)
\end{gathered}
$$

292

Where $\mathrm{p}$ expresses the various pollutants, $\mathrm{p}=\left\{\mathrm{CO}_{2}, \mathrm{NOx}, \mathrm{SOx}\right\}$, thus having in total four separate objective functions. Other pollutants that affect the environmental footprint of the ship energy systems can be included in the objective function, such as Particulate Matter, methane or Volatile Organic Compounds, by introducing additional indicators.

The optimisation decision variables are as follows:

- The main engine type $\left(\mathrm{t}_{\mathrm{me}}\right)$, the nominal power $\left(\mathrm{P}_{\mathrm{n}, \mathrm{me}}\right)$ and the fuel type $\left(\mathrm{f}_{\mathrm{me}}\right)$ for the propulsion subsystem (ps). The nominal power is considered an integer variable for the purposes of this work and the values of the decision variable increase with a $200 \mathrm{~kW}$ step.

- The auxiliary engine type $\left(t_{a e}\right)$, the number of auxiliary sets $\left(\mathrm{N}_{\mathrm{ae}}\right)$ and the fuel type $\left(\mathrm{f}_{\mathrm{ae}}\right)$ for the auxiliary electric subsystem (es).

- The boiler type $\left(\mathrm{t}_{\mathrm{th}}\right)$, the number of the boilers $\left(\mathrm{N}_{\mathrm{th}}\right)$ and the fuel type $\left(\mathrm{f}_{\mathrm{th}}\right)$ for the thermal subsystem (ts).

- The existence $\left(b_{z}\right)$ of a particular energy efficiency technology for the energy efficiency technologies subsystem (ee), where $b_{z}=\left\{1\right.$ if the technology $t_{z}$ is selected or 0 if it is not $\} . z=1 \ldots O_{e e}$ is a set of alternative technologies for energy efficiency.

- The existence $\left(b_{\mathrm{p}, \mathrm{y}}\right)$ of a particular emission reduction technology, for the energy reduction technologies subsystem (er) for each pollutant $p$, where $b_{p, y}=\left\{1\right.$ if the technology $t_{y}$ is selected or 0 if it is not $\}$ and $\mathrm{y}=1 \ldots \mathrm{O}_{\mathrm{er}, \mathrm{p}}$ is a set of alternative technologies for emission reduction for each pollutant $\mathrm{p}$.

In the environmental objectives of the optimisation problem represented by Equation (6), the first three right-hand side terms are calculated according to Equations (2) and (3) depending on the pollutant, whereas the last term represents the reduction of the emissions due to the emission reduction technologies.

The capital expenditure of the energy systems in Equation (5) is calculated according to Equation (7). 


$$
\begin{aligned}
\text { CAPEX }=C_{c\left(t_{m e)}\right.} & P_{n, m e}+C_{c\left(t_{a e}\right)} N_{a e} P_{n, a e}+C_{c\left(t_{t h)}\right.} N_{t h} P_{n, t h}+\sum_{p=1}^{N P} \sum_{y=1}^{O_{e r, p}}\left(b_{y, p} C_{c\left(t_{y}\right)} P_{n, m e}\right) \\
& +\sum_{z=1}^{O_{e e}}\left(b_{z} C_{c\left(t_{z}\right)} P_{n, m e}\right)
\end{aligned}
$$
and is derived from literature and manufacturer data. costs (OPEX1) which are calculated according to Equation (8).

$$
\begin{aligned}
\text { OPEX1 }=\frac{C_{f\left(f_{m e}\right)}}{10^{6}} \sum_{i=1}^{I}\left(c f_{\left(f_{m e}\right)} s f c_{i, m e} P_{i, m e} h_{i} d_{f, i, m e}\right) \\
+\frac{C_{f\left(f_{a e}\right)}}{10^{6}} N_{a e} \sum_{i=1}^{I}\left(c f_{\left(f_{a e}\right)} s f c_{i, a e} P_{i, a e} h_{i} d_{f, i, a e}\right) \\
+\frac{C_{f\left(f_{t h}\right)}}{10^{6}} N_{t h} \sum_{i=1}^{I}\left(c f_{\left(f_{t h}\right)} s f c_{i, t h} P_{i, t h} h_{i}\right)
\end{aligned}
$$
is the correction factor of the fuel from ISO to actual conditions; $d_{f}$ is the deterioration factor of the engine performance due to the fouling and wearing of its components, causing an increase of the fuel consumption, and it is modelled according to [88] as a varying parameter throughout the engine lifetime. calculated according to Equation (9).

$$
\begin{aligned}
\text { OPEX2 }=C_{m\left(t_{m e}\right)} & \sum_{i=1}^{I}\left(P_{i, m e} h_{i}\right)+C_{m\left(t_{a e}\right)} N_{a e} \sum_{i=1}^{I}\left(P_{i, a e} h_{i}\right)+C_{m\left(t_{t h}\right)} N_{t h} \sum_{i=1}^{I}\left(P_{i, t h} h_{i}\right) \\
& +\sum_{p=1}^{N P}\left(\sum_{y=1}^{o_{e r, p}}\left(b_{y, p} C_{m\left(t_{y}\right)} \sum_{i=1}^{I}\left(P_{i, y} h_{i}\right)\right)+\sum_{y=1}^{o_{e r, p}}\left(b_{y, p} C_{c o n\left(t_{y}\right)}\right)\right) \\
& +\sum_{z=1}^{o_{e e}}\left[b_{z} C_{m\left(t_{z}\right)} \sum_{i=1}^{I}\left(P_{i, z} h_{i}\right)\right]
\end{aligned}
$$



literature and manufacturer data, whereas $\mathrm{C}_{\text {con }}(€)$ is the cost of consumable chemicals required for the operation of the emission reduction technologies. and design constraints.

The considered regulatory constraints are as follows.

329

- $\quad \mathrm{P}_{\mathrm{n}, \mathrm{me}} \geq \mathrm{P}_{\mathrm{mpr}}$, the nominal power of the main engine has to fulfil the minimum power requirements according to the regulations [67].

- The fuel sulphur content has to comply with the existing limitations; $\mathrm{S} \% \leq 3.5 \%$ for outside ECA waters and $\leq 0.5 \%$ inside ECA waters [65] or otherwise a scrubber has to be employed.

- The NOx Emission Factors for main and auxiliary engines have to comply with the existing limitations; $\mathrm{EF}_{\mathrm{NOx}}$ to fulfil Tier II limits outside ECA waters and Tier III inside ECA waters [66].

- The nominal power of the thermal and electric auxiliaries selected has to satisfy the maximum power demand.

The considered demand-related constraints are as follows.

- The operational profile is divided in $I$ operational phases and the power demand for each operational phase $i$ has to be satisfied for each type of energy vector.

$$
P_{p p_{i}}-P_{p d_{i}}=0
$$

$$
P_{e p_{i}}-P_{e d_{i}}=0
$$

$P_{t p_{i}}-P_{t d_{i}}=0$, where $\mathrm{i}=1 \ldots$ I denoting the operational phases.

The considered technical constraints are as follows.

- The incompatibility of technologies is considered and modelled through constraints so that non-compatible technologies are not selected within a single system configuration.

The considered design constraints are as follows.

- The selection of the main engine, and multiple auxiliary and thermal boilers, in order to cover the adequate capacity of ship operation and comply with the redundancy requirements. 
The problem presented is a Multi-Objective Combinatorial Optimisation (MOCO) problem since the decision variables are discrete and the objective functions, as well as the constraints, can take any form [89]. A MOCO problem can be transformed into a single-objective by using a scalar function by employing the weighted sum method to aggregate the objectives into a single objective, which is one of the most commonly used methods in supporting decisions for enhancing sustainability [90]. However, it requires 'a priori knowledge' of the decision makers preferences [89] and using weights leads into leaving regions of solutions unmapped [91]. On the other hand, using separate objectives allows the trade-offs among the objectives to be demonstrated, and subsequently, it is possible for the user to make more informed decisions [92]. Thus, the latter approach is adopted in this work. Evolutionary algorithms are the state-of-the-art techniques in solving multi-objective optimisation problems [93] and are commonly used to solve MOCO problems. One of the most frequently used methods is the Non-dominated Sorting Genetic Algorithm II (NSGA-II) [89] that was developed by Deb et al. [94]. In this work, the NSGA-II optimisation method was employed in order to determine the Pareto front of the investigated problem. The NSGA-II is suitable for MOCO problems and it works efficiently on problems such as the one described herein, where the objective function and constraints are derived from a black box simulation. It offers a uniform distribution of the solutions on the Pareto front due to the crowding distance metric and favours solutions that are quite diverse, due to the elitist mechanism it employs. It is a method widely used for energy systems design [95-98], ship energy systems design [48,55,99-101] as well as optimisation of energy systems with sustainability considerations [102,103].

The genetic algorithm parameters were calibrated after experimentation and repeated runs. The mutation operator follows a Gaussian distribution, the crossover is set as arithmetic, the population selection is set as tournament, whereas the population size was set to 500 to offer a rich set of solutions that approximate the Pareto front.

Since the multi-objective optimisation offers a spectrum of optimum solutions in comparison with the single objective optimisation, it makes it challenging to identify an optimum solution and therefore, the Pareto optimal front is introduced. A solution from a multi-objective optimisation belongs to the Pareto front and is considered Pareto-optimal and non-dominated when there is no other solution in the solution space that performs equal in all objectives and better in at least one of them. The Pareto-optimal solutions cannot be improved in one objective without deteriorating at least in one other objective. The Pareto front offers a visual 
representation of the set of non-dominated optimal solutions, thus allowing the decision maker to explore the optimum alternatives and the trade-offs among them. In this work, the results from the multi-objective optimisation are visualised through a Pareto front.

\section{Case Study}

A case study was performed in order to exemplify the method presented in this work. The environmental and economic performance of alternative energy system configurations of an Aframax crude oil tanker having a deadweight of 115000 tons was investigated. It was assumed that the ship sails $10 \%$ of the time at ECA waters. The lifetime of the vessel was assumed to be 25 years, whereas the ship does not operate due to maintenance for $7 \%$ of her lifetime.

The data for the operational profile (speed distribution, frequency of occurrence) in ballast and laden conditions for an Aframax tanker were taken from [61]. By using the speed distribution and the ship characteristics the propulsion power was calculated according to empirical formulas provided in [104], whilst the electric power and thermal operational profile figures were estimated according to operational measured data. The considered operating profiles are shown in Fig. 3.

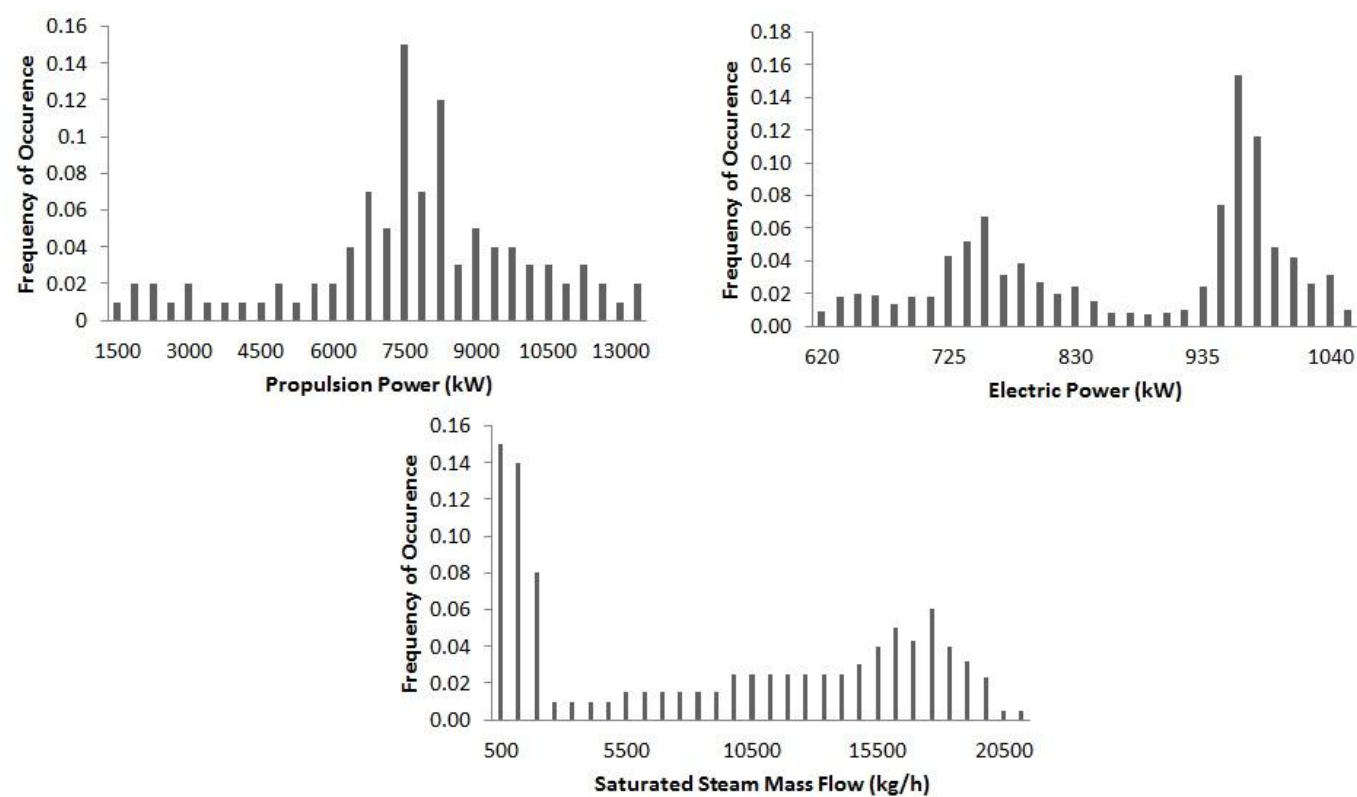

\section{Figure 3 Typical Operational Profiles for Aframax tankers}




\begin{tabular}{|c|c|}
\hline \multirow[t]{2}{*}{ Main Engine } & two-stroke diesel engine (D) \\
\hline & two-stroke gas injection dual fuel engine (DF) \\
\hline \multirow[t]{5}{*}{ Main Engine Fuel Type } & HFO \\
\hline & LSHFO \\
\hline & MDO \\
\hline & MGO \\
\hline & $\mathrm{NG}^{1}$ \\
\hline \multirow[t]{3}{*}{ Auxiliary Engine } & diesel generator set \& SCR (DG) \\
\hline & molten carbon fuel cell with NG reformer (FC) \\
\hline & pre-mixed dual fuel generator set (DFG) \\
\hline \multirow[t]{4}{*}{ Auxiliary Engine Fuel Type } & LSHFO \\
\hline & MDO \\
\hline & MGO \\
\hline & $\mathrm{NG}^{1}$ \\
\hline \multirow[t]{2}{*}{ Thermal Boiler } & gas fired boiler \\
\hline & oil fired boiler \& SCR \\
\hline \multirow[t]{5}{*}{ Thermal Boiler Fuel Type } & $\mathrm{HFO}$ \\
\hline & LSHFO \\
\hline & MDO \\
\hline & MGO \\
\hline & $\mathrm{NG}^{1}$ \\
\hline \multirow[t]{2}{*}{ Energy Efficiency Technologies } & Waste Heat Recovery with Turbo generator (WHR) \\
\hline & Shaft Generator \\
\hline \multirow[t]{2}{*}{ NOx emission reduction technologies } & Exhaust Gas Recirculation (EGR) \\
\hline & Selective Catalytic Reactor (SCR) \\
\hline \multirow[t]{2}{*}{ SOx emission reduction technologies } & fuel switch (MGO, MDO, LSHFO) \\
\hline & Scrubber \\
\hline $\mathrm{CO}_{2}$ emission reduction technologies & Carbon Capture system (CC) \\
\hline
\end{tabular}

398 For the investigated vessel, the subsystem options presented in Table 3 were considered as alternatives for the configurations considered in the proposed method application. Not all the potential combinations among the subsystems in Table 3 are possible; the compatibility of the various subsystems combinations is ensured through the technical constraints.

The following assumptions were employed for the presented case study. For the efficiency of the fuel cells, the reformer, DC-AC inverter and frequency converter efficiencies were considered, leading to a $42 \%$ alternating current electric efficiency, which is assumed to be constant with the load. The weight and volume of the technologies were not included in the scope of this work, and no economic profit was assumed from potential selling of the by-products of the carbon capture. The effectiveness of the NOx emission reduction 
407

408

409

410

411

412

413

Table 4: Fuel Cost Factors $\left(C_{f}\right)$

\begin{tabular}{lc}
\hline & Price (€/t) \\
HFO (IFO 380) & 260 \\
LSHFO (LS380) & 300 \\
MDO & 430 \\
MGO & 500 \\
NG & 235
\end{tabular}

414

415

416 market prices. industry (total EU-28) according to [106].

technologies was modelled according to [105], whereas it was assumed that the scrubber reduces the sulphur content so that the ship complies with the ECA and global water regulations for SOx emissions. The Carbon Capture system is assumed to capture $10 \%$ of the $\mathrm{CO}_{2}$ emissions from the main engine.

The average values from online bunker prices for the first six months of the year 2017 were considered as provided in Table 4. The urea price is assumed $350 € / t$ and caustic soda price is $300 € / t$ according to current

The equipment capital cost and maintenance cost were adapted from the literature or technical reports and are displayed in Table 5. The prices were converted to 2017 values using the Producer Prices Index in the

Table 5: Economic Input (components capital $C_{c}$ and maintenance cost $C_{m}$ factors)

\begin{tabular}{|c|c|c|c|c|}
\hline & $\begin{array}{l}\text { Capital Cost } \\
(€ / \mathbf{k W})\end{array}$ & $\begin{array}{l}\text { Adapted } \\
\text { from }\end{array}$ & Maintenance Cost & $\begin{array}{l}\text { Adapted } \\
\text { from }\end{array}$ \\
\hline Carbon Capture system ${ }^{2,5}$ & 2600 & [107] & $3 \%$ of capex $(€)$ & [107] \\
\hline Diesel Engine $^{3}$ (2-stroke) & 462 & {$[30]$} & $0.002(€ / \mathrm{kWh})$ & [108] \\
\hline Diesel Generator Set & 493 & {$[44]$} & $0.012(€ / \mathrm{kWh})$ & {$[92]$} \\
\hline Dual Fuel Engine ${ }^{3}$ (2-stroke) & 700 & [109] & $0.003(€ / \mathrm{kWh})$ & [108] \\
\hline Dual Fuel Generator Set & 740 & [109] & $0.012(€ / \mathrm{kWh})$ & [92] \\
\hline $\mathrm{EGR}^{5}$ & 80 & [110] & $0.001(€ / \mathrm{kWh})$ & [110] \\
\hline \multirow[t]{2}{*}{ Fuel Cells ${ }^{4}$} & 5198 & {$[51]$} & $0.035(€ / \mathrm{kWh})$ & [111] \\
\hline & & & $\begin{array}{l}\text { stack replacement } 240(€ / \mathrm{kW}) \text { every } 5 \\
\text { years }\end{array}$ & [51] \\
\hline Thermal Boiler & 22 & [112] & $1 \%$ of capex $(€)$ & [112] \\
\hline Scrubber $^{5}$ & 135 & [113] & $0.395\left(€ / \mathrm{kg} \mathrm{SO}_{2}\right.$ removed $)$ & [113] \\
\hline $\mathrm{SCR}^{5}$ & 39 & [44] & $0.006(€ / \mathrm{kWh})$ & {$[114]$} \\
\hline Shaft Generator ${ }^{5}$ & 147 & [115] & $0.001(€ / \mathrm{kWh})$ & [116] \\
\hline Waste Heat Recovery System ${ }^{5}$ & 100 & [44] & $0.004(€ / \mathrm{kWh})$ & [117] \\
\hline
\end{tabular}



been adapted from $[84,85,87]$.

Table 6: Environmental Input

\begin{tabular}{lccc}
\hline & $\begin{array}{c}\mathbf{C O}_{2} \\
(\mathbf{g} / \mathbf{g} \text { of fuel })\end{array}$ & Sulphur content (\%) & Lower Heating Value (kJ/kg) \\
HFO & 3.021 & 2.7 & 39000 \\
LSHFO & 3.075 & 0.1 & 42500 \\
MDO & 3.082 & 0.1 & 42700 \\
MGO & 3.082 & 0.1 & 42800 \\
NG & 2.75 & 0 & 48600 \\
NG \& MDO pilot fuel ${ }^{6}$ & 2.77 & 0.1 & 48600 \\
\hline${ }^{6} E F_{C O 2}=0.94 E F_{C O 2, N G}+0.06 E F_{C O 2, M D O}$ & &
\end{tabular}

Table 7: Environmental Input (NOx EF)

\begin{tabular}{lcc}
\hline & NOx Emission Factor & Adapted from \\
Diesel Engine & According to Tier II \& Tier III regulations & {$[66]$} \\
Dual Fuel Engine (in gas mode) & $8.7(\mathrm{~g} / \mathrm{kWh})$ & {$[118]$} \\
Molten Carbon Fuel Cell & $0.08(\mathrm{~g} / \mathrm{kg}$ fuel $)$ & {$[52]$} \\
Oil Fired Boiler & $5.6(\mathrm{~g} / \mathrm{L}$ fuel $)$ & {$[119]$}
\end{tabular}

The parameters for the specific case study for the performance of the two-stroke diesel and dual fuel engines with nominal power varying between $5500-42390 \mathrm{~kW}$ are given in Tables 8 and 9 , respectively. Representative figures with the raw data points used for the regression are presented in Appendix A for one nominal power ${ }^{7}$. The power range considered for the auxiliary generator sets is $500-1470 \mathrm{~kW}$.

431 Table 8: Diesel engines performance: MCR power in the range $5500(\mathrm{~kW})$ to $42390(\mathrm{~kW})$

\begin{tabular}{|c|c|c|c|c|}
\hline \multicolumn{5}{|c|}{ Specific Fuel consumption (g/kWh) } \\
\hline$a_{1}$ & $a_{2}$ & $a_{3}$ & $a_{4}$ & $L=P / P_{n}(-)$ \\
\hline 140 & 0 & 206.88 & $-196.210^{-6}$ & $<0.2$ \\
\hline-25.042 & $1810^{-7}$ & 183.996 & $-196.710^{-6}$ & $0.2 \leq L<0.6$ \\
\hline-8.179 & $-3.6110^{-6}$ & 174.797 & $-193.310^{-6}$ & $0.6 \leq L<0.7$ \\
\hline 4.862 & $-2.78110^{-6}$ & 165.364 & $-193.710^{-6}$ & $0.7 \leq L<0.8$ \\
\hline 17.623 & $4.5610^{-7}$ & 154.974 & $-190.810^{-6}$ & $0.8 \leq L \leq 1$ \\
\hline \multicolumn{5}{|c|}{ Nominal speed at MCR (r/min) } \\
\hline$a_{5}$ & $a_{6}$ & & & \\
\hline 126 & $-136.510^{-5}$ & & & \\
\hline \multicolumn{5}{|c|}{ Exhaust gas mass flow rate $(\mathrm{kg} / \mathrm{s})$} \\
\hline$a_{7}$ & $a_{8}$ & $a_{9}$ & $a_{10}$ & \\
\hline-0.342 & $0.19310^{-2}$ & $0.03110^{-2}$ & -0.052 & \\
\hline
\end{tabular}

${ }^{7}$ The regression data were derived from the Project Guide of manufacturers and are available from the corresponding author upon request. 
Exhaust gas temperature $\left({ }^{\circ} \mathrm{C}\right)$

\begin{tabular}{cccccccc}
\hline$a_{11}$ & $a_{12}$ & $a_{13}$ & $a_{14}$ & $a_{15}$ & $a_{16}$ & $a_{17}$ & $a_{18}$ \\
\hline 862.217 & $-7.410^{-5}$ & -1547.82 & $-10710^{-6}$ & 825.163 & -0.0971 & 116.844 & $-0.03610^{-2}$ \\
\hline
\end{tabular}

Table 9: Dual fuel GI engines performance: MCR power in the range $5500(\mathrm{~kW})$ to $42390(\mathrm{~kW})$

\begin{tabular}{|c|c|c|c|c|c|}
\hline \multicolumn{6}{|c|}{ Specific Pilot fuel consumption (g/kWh) } \\
\hline$b_{1}$ & $b_{2}$ & $b_{3}$ & $b_{4}$ & $b_{5}$ & $b_{6}$ \\
\hline $4.70210^{-10}$ & $-2.81810^{-5}$ & 5.333 & $5.2310^{-13}$ & $-3.13210^{-8}$ & -0.666 \\
\hline \multicolumn{6}{|c|}{ Specific Gas consumption (g/kWh) } \\
\hline $\boldsymbol{b}_{7}$ & $\boldsymbol{b}_{8}$ & $b_{9}$ & $b_{10}$ & $b_{11}$ & $b_{12}$ \\
\hline 30 & $4.810^{-5}$ & 31.564 & $5.4210^{-5}$ & 143.78 & $-1.510^{-4}$ \\
\hline
\end{tabular}

Nominal speed at MCR (r/min)

\begin{tabular}{ll}
\hline $\boldsymbol{b}_{13}$ & $\boldsymbol{b}_{14}$ \\
\hline $126 \quad-136.510^{-5}$
\end{tabular}

Exhaust gas mass flow rate $(\mathrm{kg} / \mathrm{s})$

\begin{tabular}{|c|c|c|c|c|c|c|}
\hline$b_{15}$ & $b_{16}$ & $b_{17}$ & $b_{18}$ & & & \\
\hline-0.342 & $0.19310^{-2}$ & $0.03110^{-2}$ & -0.052 & & & \\
\hline \multicolumn{6}{|c|}{ Exhaust gas temperature $\left({ }^{\circ} \mathrm{C}\right)$} & $L=P / P_{n}(-)$ \\
\hline$b_{19}$ & $b_{20}$ & $b_{21}$ & $b_{22}$ & $b_{23}$ & $b_{24}$ & \\
\hline-2857 & 0 & 0 & 1390.9 & 62.108 & $-0.03410^{-2}$ & $<0.3$ \\
\hline 0 & 0 & 0 & 840 & -28.642 & $-0.04410^{-2}$ & $0.3 \leq L \leq 0.35$ \\
\hline 287 & $-0.6710^{-4}$ & $9.0310^{-5}$ & -421.24 & 380.652 & $-0.03710^{-2}$ & $>0.35$ \\
\hline
\end{tabular}

The data presented in this section are used as input parameters for the application of the proposed method.

\section{Results and Discussion}

Representative results from the optimisation process for the investigated Aframax tanker are presented in this section to demonstrate the application of the method. The Pareto front curves are displayed both for a biobjective optimisation scenario, where only two objectives were considered in the optimisation and a multiobjective optimisation scenario, where all four objectives were included in the optimisation process. Each point of the curve represents an optimum ship energy system configuration according to the considered objectives. All

441 the presented solutions comply with the IMO Annex VI regulations for NOx and SOx emissions [65,66], as well

442 as the EEDI regulations for energy efficiency. Finally, a preliminary sensitivity analysis was performed in order

\subsection{Bi-objective optimisation results}



presented in Figure 4. Figure 4a shows the complete solution space with light grey colour, whereas the Pareto front that includes the optimum non-dominated solutions is presented with black colour. In Figure 4b, only the Pareto front results are displayed with more detail. From Figure 4a, it is evident that a variety of solutions exist in the solution space and the optimisation method was able to identify the optimum solutions in the Pareto front (black marks). It is inferred that among the solutions on the solutions space there are many alternatives that are not efficient in terms of environmental and economic objectives.

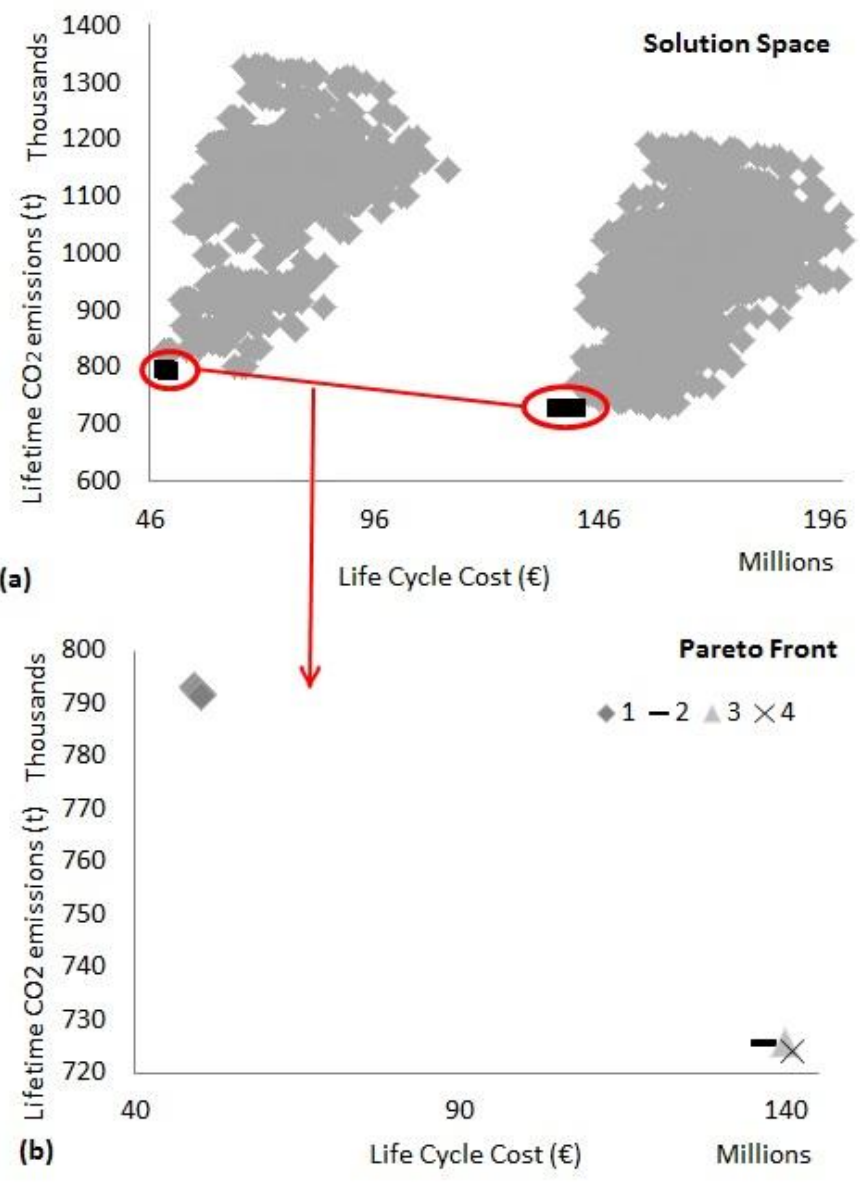

The Pareto Front shown in Figure 4b displays a variety of solutions for the investigated ship energy systems configurations. The set of optimal solutions is presented in Table 10. It is evident from the results of the biobjective optimisation that the dual fuel engine running with natural gas and a range of nominal power varying between 17300 and $18800 \mathrm{~kW}$, as well as the gas fired boiler, are dominant components. Solutions for the auxiliary electric sub-system include either diesel generators running with LSHFO (solutions 1, 2 and 3), which has a low capital cost but emits more $\mathrm{CO}_{2}$ emissions, or a dual fuel generator running with natural gas (solution 

generators are selected; two with the maximum nominal power that is required by the regulations and one with a smaller nominal power to operate more efficiently at the lower loads range. In addition, in some cases the Carbon Capture technology is selected (2,3 and 4), thus reducing the $\mathrm{CO}_{2}$ emissions drastically, however significantly increasing the LCC due to the high capital, as well as the operational cost of this technology. By installing a Carbon Capture system there is a cost increase of $1.29 €$ per $\mathrm{kg}$ of $\mathrm{CO}_{2}$ emissions saved. The carbon emissions reduction in solution 2 is $10 \%$ lower in comparison with the ones of solution 1 over the ship lifetime; however, the life cycle cost is almost tripled due to the emissions reduction technology. The installation of the Carbon Capture system has an additional economic drawback, which is the occupation of approximately $0.15 \%$ of the payload of the vessel per day of sailing, resulting in lower revenues from operations. This additional economic impact has not been accounted in this research. Ultimately, comparing the last six months average price of $5.93 €$ per ton of $\mathrm{CO}_{2}$ of the EU ETS with the cost of $1290 €$ per ton of $\mathrm{CO}_{2}$ that is offered with the Carbon Capture renders the technology prohibitive in the real-life context for the particular application, despite the significant carbon emissions reduction.

Table 10: Configurations of Figure 4

\begin{tabular}{|c|c|c|c|c|c|c|c|c|c|}
\hline & \multicolumn{2}{|c|}{ Main Engine } & \multirow{2}{*}{$\begin{array}{l}\text { Emission } \\
\text { reduction } \\
\text { technology }\end{array}$} & \multirow{2}{*}{$\begin{array}{l}\text { Energy } \\
\text { Efficiency } \\
\text { technology }\end{array}$} & \multicolumn{2}{|c|}{ Auxiliary engine } & & \multicolumn{2}{|c|}{ Boiler } \\
\hline & Type & Fuel & & & Type & Fuel & $\begin{array}{l}\text { Sets/ } \\
\text { Nominal } \\
\text { power }\end{array}$ & Type & Fuel \\
\hline 1 & DF & NG & SCR & WHR\&SG & DG & LSHFO & $2 / 1136 \mathrm{~kW}$ & gas fired & NG \\
\hline 2 & DF & NG & SCR\&CC & SG & DG & LSHFO & $\begin{array}{l}2 / 1136 \mathrm{~kW} \\
\& 1 / 500 \mathrm{~kW}\end{array}$ & gas fired & NG \\
\hline 3 & DF & NG & EGR\&CC & SG & DG & LSHFO & $\begin{array}{l}2 / 1136 \mathrm{~kW} \\
\& 1 / 500 \mathrm{~kW}\end{array}$ & gas fired & NG \\
\hline 4 & DF & NG & EGR\&CC & SG & DFG & NG & $2 / 1110 \mathrm{~kW}$ & gas fired & NG \\
\hline
\end{tabular}
objectives the lifetime SOx emissions and the Life cycle cost are displayed. In Figure 5a, the variety of solutions of the complete solution space is presented with a wide range of the values of the objectives. The solutions on the complete solutions space include also non-efficient technologies. Due to the wide scaling of this plot vertical axis it appears that there is a variety of solutions with similar SOx lifetime emissions to the Pareto optimal solutions at the bottom of the vertical axis; however, a closer look at these solutions reveals that the SOx emissions actually vary considerably between the optimal solutions identified (highlighted in black) and the 
non-optimal solutions (in grey). The non-dominated solutions of the Pareto front that perform better in both objectives are highlighted and displayed in Figure $5 b$.

In Figure 5b, two sets of alternative ship energy system configurations for the investigated Aframax are identified in the Pareto front. The configurations of Figure $5 \mathrm{~b}$ are detailed in Table 11. In both solutions, the dual fuel engine is preferred as the main engine as well as the gas fired boiler as the system thermal energy producer. The nominal power of the main engine is in the range of $17300-18800 \mathrm{~kW}$. The main difference between the two solutions lies in the auxiliary electric engine; in solution 1, two diesel generator sets running with LSHFO are selected, whereas in solution 2 dual fuel generator sets were selected. It is evident from the performance of the solutions that the natural gas on the generators offers a reduction in the SOx emissions, however at the same time due to the higher cost of the dual fuel generator sets, an increase in the Life Cycle Cost is observed. From the installation of the dual fuel generator sets (solution 2) instead of the typical diesel generator sets (solution 1), a cost increase of around $37 €$ per $\mathrm{kg}$ of SOx emissions saved is identified. It is inferred from these results that a configuration with all the main energy systems running with natural gas, offers the minimum SOx emissions and therefore, it is recognised as a possible configuration to comply with the future stricter regulations imposed by IMO. 


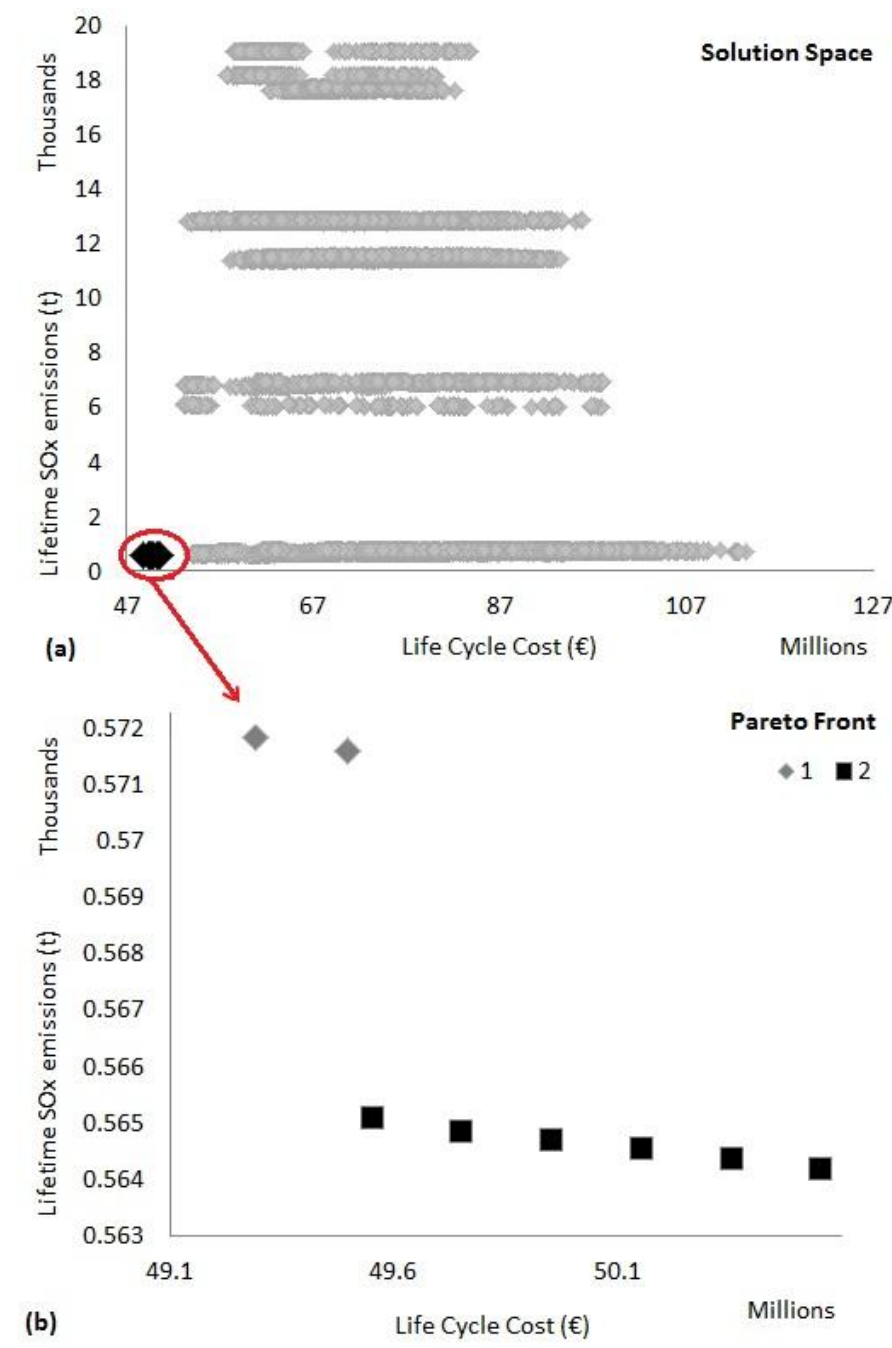

497

Figure 5 SOx-LCC bi-objective optimisation: a) Solution Space b) Pareto Front

Table 11: Configurations of Figure 5

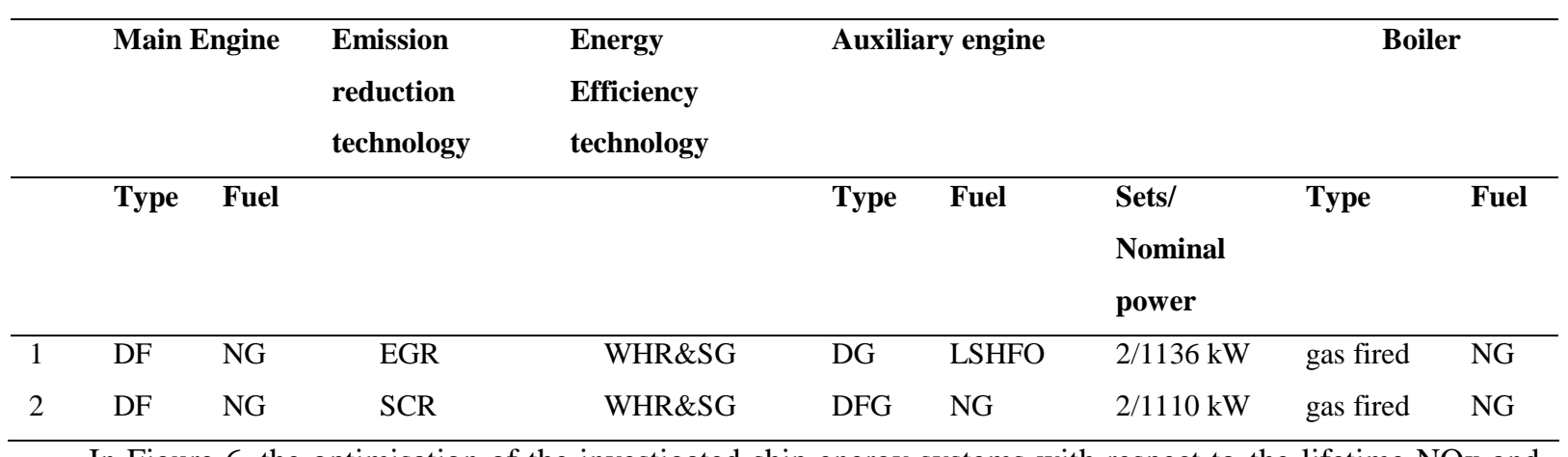

500 In Figure 6, the optimisation of the investigated ship energy systems with respect to the lifetime NOx and

501 LCC objectives is presented. The solution space of the bi-objective optimisation is displayed in Figure 6a where

502 the non-dominated solutions are presented in black. 


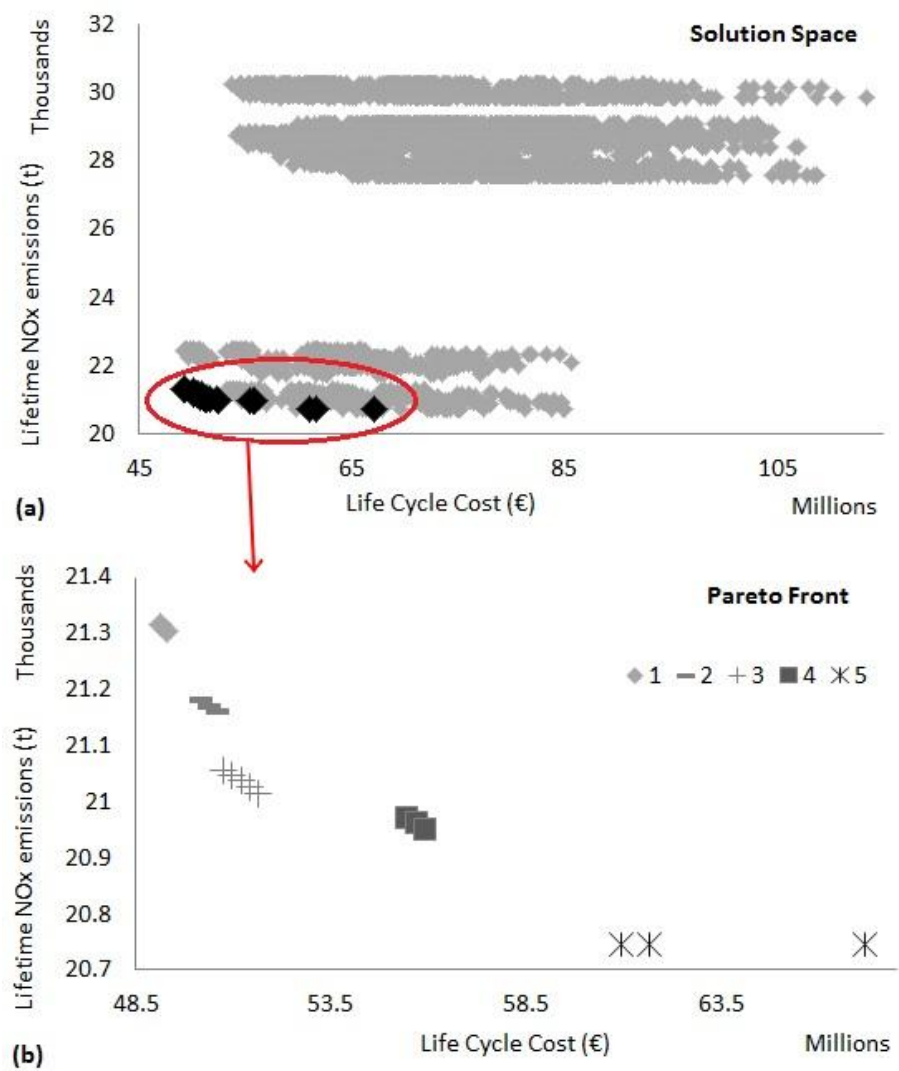

Table 12: Configurations of Figure 6

\begin{tabular}{|c|c|c|c|c|c|c|c|c|c|}
\hline & \multicolumn{2}{|c|}{$\begin{array}{c}\text { Main } \\
\text { Engine }\end{array}$} & \multirow{2}{*}{$\begin{array}{l}\text { Emission } \\
\text { reduction } \\
\text { technology }\end{array}$} & \multirow{2}{*}{$\begin{array}{c}\text { Energy } \\
\text { Efficiency } \\
\text { technology }\end{array}$} & \multicolumn{3}{|c|}{ Auxiliary engine } & \multicolumn{2}{|c|}{ Boiler } \\
\hline & Type & Fuel & & & Type & Fuel & $\begin{array}{c}\text { Sets/ } \\
\text { Nominal } \\
\text { Power }\end{array}$ & Type & Fuel \\
\hline 1 & $\mathrm{DF}$ & NG & SCR & WHR\&SG & DG & LSHFO & $2 / 1136 \mathrm{~kW}$ & gas fired & NG \\
\hline 2 & DF & NG & EGR & WHR\&SG & DFG & NG & $2 / 1110 \mathrm{~kW}$ & gas fired & NG \\
\hline 3 & DF & NG & EGR\&SCR & WHR\&SG & DG & LSHFO & $2 / 1136 \mathrm{~kW}$ & gas fired & NG \\
\hline 4 & $\mathrm{DF}$ & NG & EGR\&SCR & WHR\&SG & DFG & NG & $2 / 1110 \mathrm{~kW}$ & gas fired & NG \\
\hline 5 & $\mathrm{DF}$ & NG & EGR\&SCR & WHR\&SG & $\mathrm{FC}$ & NG & $2 / 1110 \mathrm{~kW}$ & gas fired & NG \\
\hline
\end{tabular}

In Figure $6 \mathrm{~b}$, the Pareto front is presented with more detail from which five different sets of solutions are

507 identified and displayed in Table 12. Similarly to the two previous cases, the dual fuel engine (with its nominal

508 power varying from 17050 to $18800 \mathrm{~kW}$ ) and the gas fired boiler are preferred; furthermore, the WHR as well

509 as the shaft generator, are selected for improving the plant energy efficiency. There are variations of the

510 solutions on the emission reduction technology so that the ship complies with the NOx regulations inside ECA 

decrease in the lifetime NOx emissions, however, followed with an $18 \mathrm{M} €$ increase in the life cycle cost, due to the operational and capital cost of the technologies. In addition, the solution with the lower lifetime NOx emissions appears when the fuel cell technology (Solution 5) is selected for covering the ship electric power demand; on the other hand, the economic objective is increased due to the high investment cost of the fuel cells technology. Comparing the two extreme solutions 1 and 5, a cost increase of $22 €$ per kg of NOx emissions saved is observed, by installing both emission reduction technologies as well as the fuel cells instead of the traditional diesel generators. Installing both emission reduction technologies is not a current practice; however, from the results, it is inferred that it is a possible alternative that could be employed in the future when the regulations for NOx emissions are going to be more stringent.

\subsection{Multi-objective optimisation results} SOx, NOx, $\mathrm{CO}_{2}$ emissions and the Life Cycle Cost are presented in Figure 7.

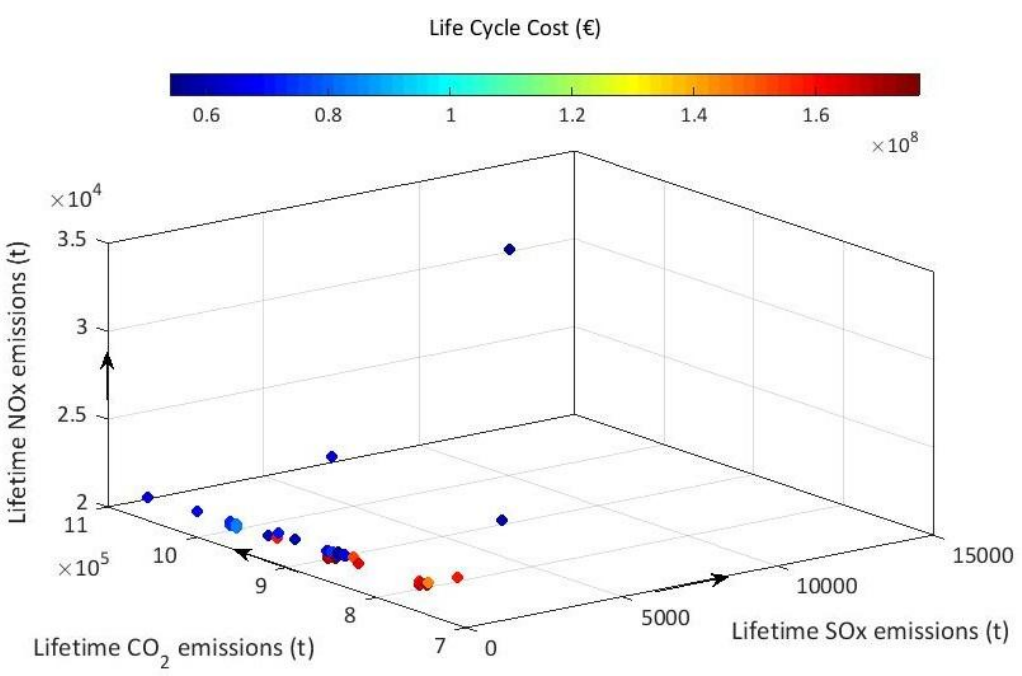
the complete view of the four-dimensional space including all dimensions of the analysis, whereas Figure 8 (a, b and c) are extracted from Figure 7 and provide a three-dimensional view of the original figure. The solutions are clustered into 13 categories; each one includes solutions having a similar configuration. The details for the solutions of Figures 7 and 8 are displayed in Table 13, where the configurations of the solutions from the multi- 
objective optimisation are displayed in detail along with the values of the objective functions, expressed as the difference from the best case. It is evident from Figures 7, that there is a variety of alternative configurations and it is not possible to identify a single optimum solution. However, a variety of environmental and cost-efficient solutions are generated supporting the decision process and giving the opportunity to the decision maker to understand the trade-offs among the objectives.
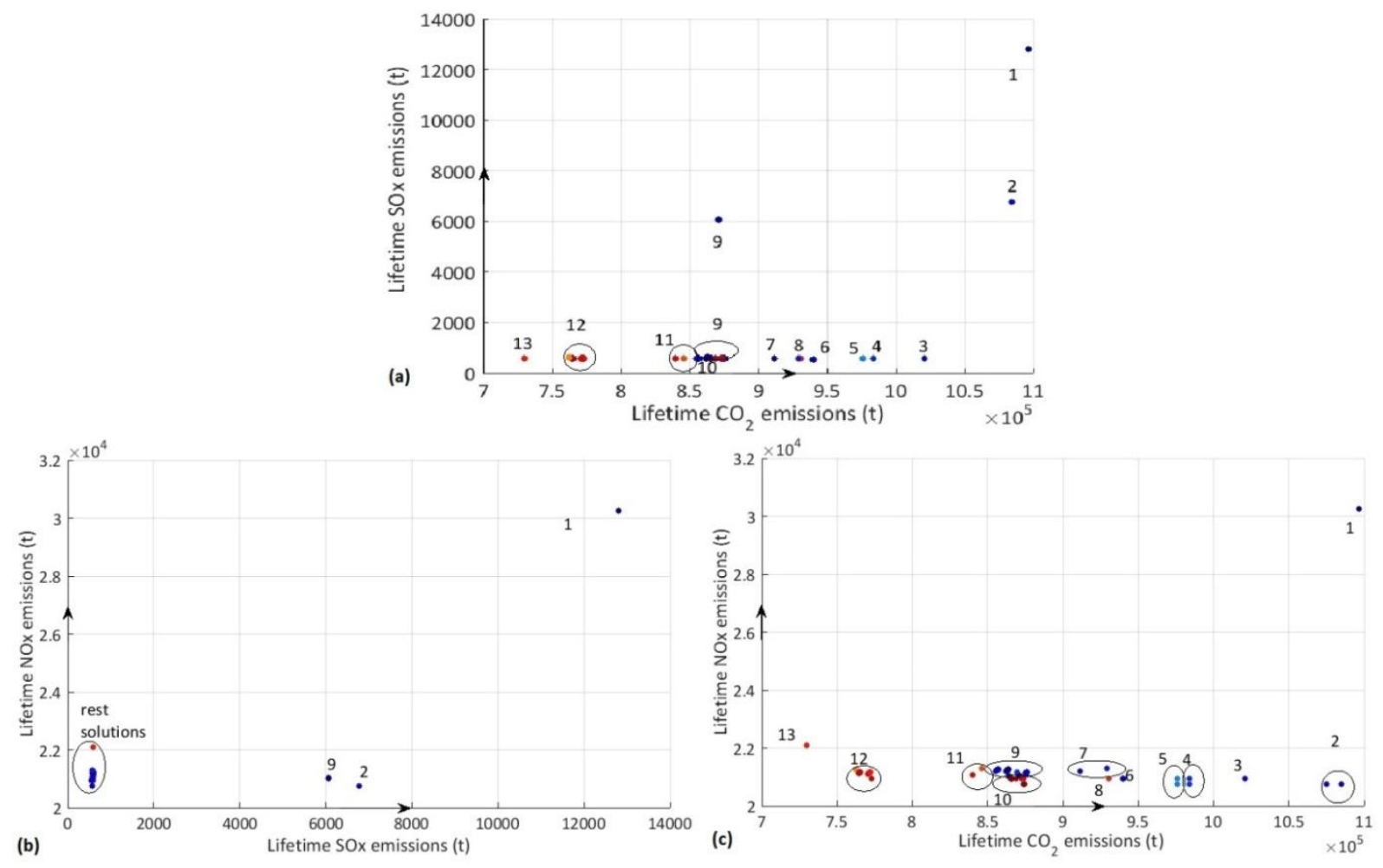

Figure 8 Multi-objective optimisation: a) SOx-CO $\mathrm{CO}_{2}-\mathrm{LCC}$ view, b)NOx-SOx-LCC view, c)NOx-CO${ }_{2}$-LCC view

It is evident from the results of Figure 7 and 8 that there are trade-offs observed, similarly to the majority of real-life problems. The solutions 1-7 and 9 appear to have LCC below $84 \mathrm{M} €$ with the solution 1 having the lowest LCC, whereas the LCC of the alternatives 8 and 10-13 is estimated to be in the region 144-180 M€. For the lifetime SOx emissions objective all the solutions, except for the solutions 1,2 and 9 are expected to emit SOx emissions below 2 thousand tonnes throughout the ship lifetime. Regarding the lifetime $\mathrm{CO}_{2}$ emissions, the solutions 12 and 13 exhibit the lowest carbon footprint with the estimated $\mathrm{CO}_{2}$ emissions being in the region of 700-800 thousand tonnes. Finally, all the solutions except for the solution 1 are estimated to have lifetime NOx emissions below 22 thousand tonnes. 
Table 13: Configurations of Figure 8

\begin{tabular}{|c|c|c|c|c|c|c|c|c|c|c|c|c|}
\hline & \multicolumn{2}{|c|}{ Main Engine } & \multirow{2}{*}{$\begin{array}{c}\text { Emission reduction } \\
\text { technology }\end{array}$} & \multirow{2}{*}{$\begin{array}{c}\text { Energy } \\
\text { Efficiency } \\
\text { technology }\end{array}$} & \multicolumn{3}{|c|}{ Auxiliary engines } & \multicolumn{2}{|c|}{ Thermal Boiler } & \multicolumn{3}{|c|}{ Percentage Difference from the best solution } \\
\hline & Type & Fuel & & & Type & Fuel & Type & Fuel & LCC & $\begin{array}{l}2 \\
\text { issions }\end{array}$ & SOx emissions & $\begin{array}{l}\text { NOx } \\
\text { emissions }\end{array}$ \\
\hline 1 & $\mathrm{D}$ & HFO & LSHFO switch \&SCR & SG & DG & LSHFO & gas fired & NG & 0 & $+50 \%$ & $+22 \%$ & $+46 \%$ \\
\hline 2 & $\mathrm{DF}$ & NG & EGR\&SCR & none & FC & NG & oil fired & $\begin{array}{l}\text { HFO \& Fuel } \\
\text { switch }\end{array}$ & $+20 \%$ & $+47 \%$ & $+11 \%$ & $+0.01 \%$ \\
\hline 3 & $\mathrm{DF}$ & NG & EGR & WHR & $\mathrm{FC}$ & NG & oil fired & $\begin{array}{l}\text { HFO \& Fuel } \\
\quad \text { Switch }\end{array}$ & $+21 \%$ & $+40 \%$ & $+6 \%$ & $+0.9 \%$ \\
\hline 4 & $\mathrm{DF}$ & NG & EGR & none & $\mathrm{FC}$ & NG & oil fired & LSHFO & $+39 \%$ & $+34 \%$ & $+5 \%$ & $+0.9 \%$ \\
\hline 5 & $\mathrm{DF}$ & NG & EGR\&SCR & none & $\mathrm{FC}$ & NG & oil fired & LSHFO & $+42 \%$ & $+34 \%$ & $+5 \%$ & $+0.002 \%$ \\
\hline 6 & $\mathrm{DF}$ & NG & EGR & WHR & DFG & NG & oil fired & LSHFO & $+20 \%$ & $+25 \%$ & $+5 \%$ & $+2.5 \%$ \\
\hline 7 & $\mathrm{DF}$ & NG & SCR & WHR & $\mathrm{FC}$ & NG & gas fired & NG & $+12 \%$ & $+29 \%$ & 0 & $+1 \%$ \\
\hline 8 & $\mathrm{DF}$ & NG & EGR\&CC & WHR & $\mathrm{FC}$ & NG & oil fired & LSHFO & $+192 \%$ & $+27 \%$ & $+5 \%$ & $+0.9 \%$ \\
\hline 9 & $\mathrm{DF}$ & NG & EGR or SCR or both & SG\&WHR & DG & LSHFO & oil fired & LSHFO & $+15-30 \%$ & $+20 \%$ & $+7-10 \%$ & $+1.5-2.5 \%$ \\
\hline 10 & $\mathrm{DF}$ & NG & $\begin{array}{c}\text { CC\& EGR or SCR or } \\
\text { both }\end{array}$ & WHR & $\mathrm{FC}$ & NG & oil fired & LSHFO & $+205-225 \%$ & $+19 \%$ & $+4.5 \%$ & $+0-1 \%$ \\
\hline 11 & $\mathrm{DF}$ & NG & CC\& EGR\& SCR & none & DFG & NG & oil fired & LSHFO & $+190 \%$ & $+15 \%$ & $+5 \%$ & $+2 \%$ \\
\hline 12 & $\mathrm{DF}$ & NG & EGR & SG\&WHR & $\mathrm{FC}$ & NG & oil fired & LSHFO & $+190-210 \%$ & $+5 \%$ & $+6 \%$ & $+1.7-2.5 \%$ \\
\hline 13 & $\mathrm{DF}$ & NG & CC\& EGR\& SCR & SG & $\mathrm{FC}$ & NG & gas fired & NG & $+193 \%$ & 0 & $+6 \%$ & $+6.5 \%$ \\
\hline
\end{tabular}

548 

the ship main engine offers a great advantage with respect to most of the objectives comparing to the diesel engines that is the current practice. Even though the capital cost of the dual fuel engine is higher, due to the required feeding and storage systems, the technology is preferred by the optimiser due to its lower fuel consumption and environmental impact; these results also confirm the findings reported in [44,45]. In addition, even when the diesel engine is selected (Solution 1) it is preferable to operate with HFO and switch to low sulphur fuel in order to comply with the SOx regulations, rather than employing a scrubber, which is the traditional emission reduction technology. Literature results support these findings for the case of the deterministic optimisation for selecting emission reduction alternatives; however, when the stochasticity of the input parameters is included the presented results in the literature vary [26]. fired boiler are the preferred solutions in order to improve the environmental and economic impact of ship energy systems. In only two cases, an oil fired boiler running with HFO and fuel switch is selected. In the existing literature, no evidence was identified to investigate the thermal boiler subsystem alternatives.

For the electric auxiliary subsystem, the most promising technologies among the investigated ones are the fuel cells, the LSHFO diesel generator sets or the dual fuel generator sets. The fuel cells have attracted great attention from the literature as despite their high economic impact they have great potential in improving the environmental impact. The results are confirmed by previous studies, where comparing to current technologies, fuel cells showed improved energy efficiency and considerable reduction environmental footprint [120].

The energy-efficient technologies of the shaft generator and WHR are selected in the majority of the solutions from the multi-objective optimisation; the inclusion of these technologies offers a cost-effective and more environmentally friendly performance for the investigated system, accordingly with the relevant literature [32]. The more efficient main engine drives the shaft generator that produces the required electric power, whereas the exhaust gas is employed from the waste heat recovery to produce steam required to cover the thermal power demand of the ship as well as to produce electric energy through the turbo-generator. Thus, whilst the capital cost increases from the installation of these technologies, the environmental and operational economic impact of the ship auxiliary electric and thermal machinery are less. 
currently associated with a substantial increase in the LCC. In addition, even though the Carbon Capture technology was successfully implemented for onshore applications, there are various challenges regarding the storage of $\mathrm{CO}_{2}$, particularly for ship applications. However, there is still a great interest in the application of Carbon Capture on ships [73,121].

\subsection{Sensitivity analysis}

As the performance of the ship energy systems is influenced by a number of parameters that are characterised by uncertainty in real life, including the operating and economic parameters, it is important to understand the effect of these parameters variation on the optimisation results. A common method to investigate the uncertainty on deterministic decision support models and thus, explore how the changes on the input parameters affect the results, is by performing a sensitivity analysis [122,123], which entails altering the input parameter values to investigate the variation of the output. Herein a preliminary sensitivity analysis was performed focusing on the uncertain variables that were considered more influential for the results.

In this analysis, the considered economic parameters include capital cost factors of the investigated technologies and the fuel prices, which are identified as the most crucial parameters for ship energy systems design and synthesis as also indicated in [43]. Different cost factors ranges are investigated for the emerging technologies (in comparison to the ones of the established technologies), due to the expected higher uncertainty resulting from the lower technology maturity level and the limited market data availability. The fuel prices values are considered to be highly correlated, in line with the historical market evidence, and are therefore expressed as a function of the HFO prices. The fuel price ranges considered for this sensitivity analysis are derived from analysing the historical prices for the HFO over the years 2007-2017. Based on further analysis of the historical prices of all fuel types, it was assumed that the price of NG, MGO, LSHFO and MDO is 0.85 , $1.95,1.2$ and 1.7 times the HFO price, respectively.

The investigated operating parameters, which are considered the most critical for the systems performance, include the brake specific fuel consumption as well as the exhaust gas temperature and mass flow rate. Reasonable ranges were estimated for the above operating parameters by using the manufacturers data [70].

The investigated parameters ranges are presented in Table 14, whereas the results from the original case study presented in Figure 7 are considered as the baseline scenario for comparison purposes. All parameters were independently assessed except the fuel prices that are considered strongly correlated. 


\begin{tabular}{lcc}
\hline Uncertain parameters & $\begin{array}{l}\text { Extreme parameter value difference from the baseline provided in } \\
\text { Tables 8 and 9 }\end{array}$ & high \\
\hline Operating parameters & $l o w$ & $+5 \%$ \\
main engine brake specific fuel consumption & - & $+5 \%$ \\
main engine exhaust gas mass flow rate & - & $+15^{\circ} \mathrm{C}$ \\
main engine exhaust gas temperature & Extreme parameter value difference from the baseline \\
\hline Economic parameters & provided in Tables $\mathbf{4}$ and $\mathbf{5}$ & \\
& & \\
\hline Technologies Cost factors & $-20 \%$ & $+20 \%$ \\
\hline dual fuel main engines & $-20 \%$ & $+20 \%$ \\
diesel main engines & $-50 \%$ & $+20 \%$ \\
Carbon capture system & $-50 \%$ & $+20 \%$ \\
Fuel Cells & $-20 \%$ & $+20 \%$ \\
SCR, EGR, scrubber & $-60 \%$ & $+60 \%$ \\
\hline Fuel prices & & \\
\hline
\end{tabular}
output consists of a four-dimensional Pareto-front of optimum solutions, there is no straightforward way to

611 consider the output as a single value for comparing it with the baseline scenario. Since the ultimate objective of this optimisation model is the identification of the set of optimal system configurations, the performance criterion adopted as an output of the sensitivity analysis was how different the system configurations in the Pareto front become as the uncertain parameters vary. Therefore in Figure 9, the vertical axes include the investigated technologies in the configurations and the horizontal axes values represent the percentage difference from the baseline scenario of the number the specific technology appears in the Pareto front to the number of all the solutions in the Pareto front. For comparison purposes, Figure 9 also informs on the frequency of appearance of each technology on the Pareto front of the baseline case, which is displayed in the bottom right corner of the figure. It should be noted that the sensitivity analysis results are also affected by the number of the optimum solutions identified in the Pareto front, which vary between different applications of the model, due to the nature of the optimisation method. Therefore, the number of optimum solutions identified in the Pareto front for each sensitivity analysis scenario is displayed in the grey boxes at the top of each graph in Figure 9. Small variations of the results can be attributed to the different number of optimum solutions; for this reason minor changes are considered insignificant and are not discussed. 

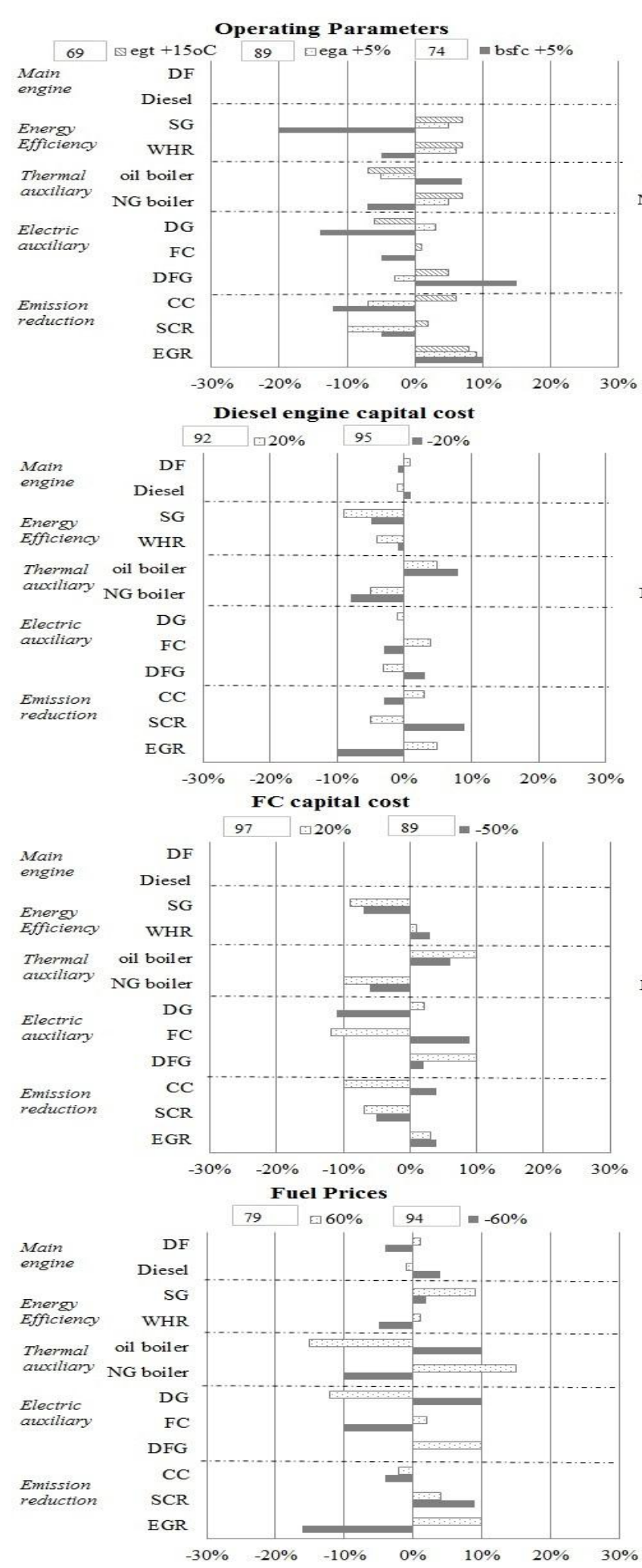

Figure 9 Sensitivity analysis results (horizontal axes represent the percentage difference from the
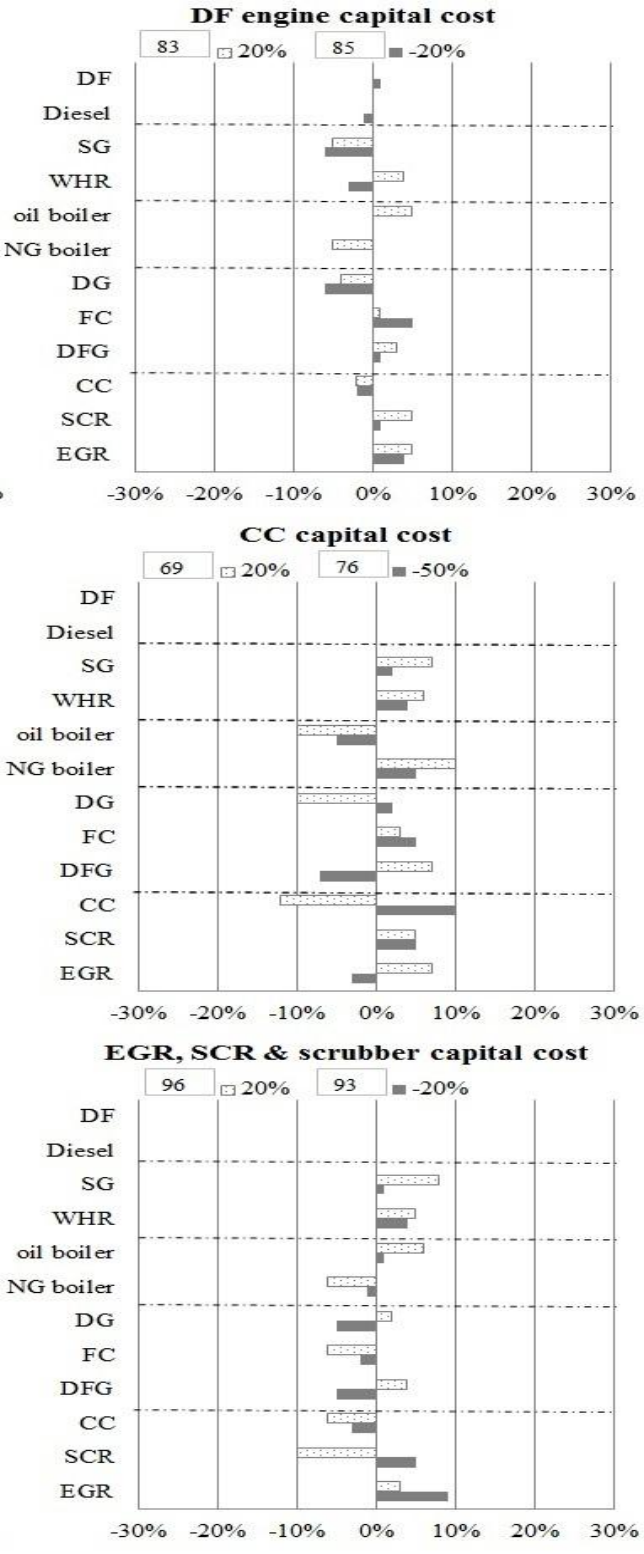

\begin{tabular}{|c|c|c|}
\hline & Baseline & 71 \\
\hline Technologies & Percentas & ges \\
\hline DF engine & & $99 \%$ \\
\hline Diesel engine & & $1 \%$ \\
\hline SG & & $70 \%$ \\
\hline WHR & & $90 \%$ \\
\hline oil boiler & & $65 \%$ \\
\hline NG boiler & & $35 \%$ \\
\hline DG & & $30 \%$ \\
\hline FC & & $55 \%$ \\
\hline DFG & & $15 \%$ \\
\hline $\mathrm{CC}$ & & $52 \%$ \\
\hline SCR & & $80 \%$ \\
\hline EGR & & $78 \%$ \\
\hline
\end{tabular}


The increase of the brake specific fuel consumption does not favour solutions with SG driven from the main

629

630

631

632

633

634

635

636

637 engine for the electric power production. Therefore, a significant reduction on the level of adoption of SG is observed and the ship electric power demand is covered by adopting dual fuel generators. The percentage of $\mathrm{CC}$ technology on the optimum solutions decreases due to the high energy penalty and as a consequence the further increase on the fuel consumed. The dual fuel engine preference as the main engine choice does not change, as it is already preferred in the vast majority of the solutions even in the baseline scenario.

The increase in the exhaust gas mass flow rate favours the selection of the WHR technology, since the wasted energy of the exhaust gas of the main engine increases. Thus, the efficiency of the power plant improves, which resulted in lowering the percentage of the CC technology in the optimal solutions. Similarly, the increase of the exhaust gas temperature leads to a higher percentage of WHR technology in the optimum solutions.

Low sensitivity is observed in the cases when the capital cost of the dual fuel main engine is altered. The decrease of the capital cost of the dual fuel engines leads to a minor increase of the percentage of optimum solutions with dual fuel engines. Considering that dual fuel engines were already selected in $99 \%$ of the solutions in the baseline scenario, this actually means that when the related capital cost is reduced, all solutions include a dual fuel main engine. On the other hand, decreasing the diesel main engines capital cost resulted in a slightly decreased percentage of optimum solutions with dual fuel engines; the opposite happens when the diesel main engine capital cost increases. By and large, the dual fuel engines appear to be the preferred main engine choice in most optimum solutions even if the capital cost difference between them and the diesel engines increases. In addition, a similar trend is observed with the NOx reduction technology selection that is affected by the main engine type selection, since the SCR is required by the diesel engine to operate with the stringent NOx limits.

Reducing the CC capital cost leads to a significantly higher adoption of the technology. The opposite occurs when the capital cost of the technology increases. Lower adoption of CC on the optimum solutions appears to have an impact on the thermal and electric auxiliary subsystems, the gas fired boiler as well as the fuel cells and dual fuel generators are favoured, respectively. These technologies are adopted instead of the oil fired boiler and diesel generators, as means of compensating for the reduction of the $\mathrm{CC}$ adoption in the optimum solutions to achieve reduction of the lifetime $\mathrm{CO}_{2}$ emissions. The variation of the fuel cells capital cost affects the technology selected to cover the electric demand; the decrease of the FC cost increases the percentage of fuel cells and at the same time decreases the percentage of diesel generators on the optimum solutions. On the other 
hand, the increase of the FC capital cost decreases the percentage of fuel cells on the solutions and favours the adoption of the dual fuel generators that exhibit lower capital cost than the fuel cells but have a lower environmental footprint comparing with the diesel generators.

The variation of the emission reduction technologies cost has an impact mostly on their adoption, with limited impact on most of the rest parameters of the investigated system configurations; it is observed that a decrease of their capital cost leads to an increase of the percentage of EGR and SCR technologies in the optimum solutions. However, the increase in the capital cost affects negatively only the SCR that has overall a higher LCC due to its high operational cost that includes both the urea consumption and the penalty on the engine efficiency. An increase is observed to the adoption of EGR in order to compensate for the reduction of SCR.

Finally, the fuel price changes have the greatest impact on the results, as it was anticipated. The decrease of the fuel prices has a negative impact on the level of adoption of the natural gas operating technologies as the HFO price becomes very competitive. More specifically, the adoption of the dual fuel engines, the fuel cells and the natural gas boiler on the optimum solutions decreases. On the other hand, in the case of the fuel price increase, the dual fuel engines, the dual fuel generators, fuel cells as well as the natural gas boiler are favoured. Changes are observed also on the emission reduction technologies selection that are related to the changes of the main engine in the optimum configurations, since the SCR is mandatory for the operation of the diesel engines, whereas the dual fuel engines can comply with the NOx emissions regulations without SCR usage.

As an additional consideration to the sensitivity analysis against the full set of Pareto-optimal solutions, the best performing solution for each objective for all the sensitivity analysis scenarios along with the differences of the optimum configuration from the baseline scenario solutions shown in Table 13 are presented in Table 15. The rationale was to identify how different the system configurations become when the input parameters change, specifically for the optimum solution identified for each objective. In the majority of the scenarios, the best solution for each objective has the same configuration with the baseline scenario solution with the exception of the scenarios in which either the dual fuel engines capital cost decreases or the diesel engines capital cost increases. In these cases, the best solutions include one dual fuel main engine and provide the best performance for both the economic and environmental objectives. For best performing at the $\mathrm{CO}_{2}$ and $\mathrm{SOx}$ emissions objectives, the investigated scenarios with the fuel cell capital cost increase and the fuel prices increase provided solutions with dual fuel generator sets. In the case when the brake specific fuel consumption 
Table 15: Best performing configuration for each objective for the sensitivity scenarios

\begin{tabular}{|c|c|c|c|c|}
\hline \multicolumn{5}{|c|}{ Differences on the optimum configuration from base case (Table 13) } \\
\hline Sensitivity analysis scenario & $\mathbf{L C C}$ & $\overline{\mathrm{CO}_{2} \text { emissions }}$ & NOx emissions & SOx emissions \\
\hline $\mathrm{bsfc}+5 \%$ & same & same & same & no WHR \\
\hline ega $+5 \%$ & same & same & same & same \\
\hline egt $+15^{\circ} \mathrm{C}$ & same & same & same & same \\
\hline DF capital cost $-20 \%$ & $\begin{array}{l}\text { DF \& EGR instead } \\
\text { of Diesel \&SCR }\end{array}$ & same & same & same \\
\hline DF capital cost $+20 \%$ & same & same & same & same \\
\hline Diesel engine capital cost $-20 \%$ & same & same & same & same \\
\hline Diesel engine capital cost $+20 \%$ & $\begin{array}{l}\text { DF \& EGR instead } \\
\text { of Diesel \&SCR }\end{array}$ & same & same & same \\
\hline CC capital cost $-50 \%$ & same & same & same & same \\
\hline CC capital cost $+20 \%$ & same & same & same & same \\
\hline FC capital cost $-50 \%$ & same & same & same & same \\
\hline FC capital cost $+20 \%$ & same & $\begin{array}{l}\text { DF Gen-set } \\
\text { instead of FC }\end{array}$ & same & $\begin{array}{l}\text { Diesel Gen-set } \\
\text { (LSHFO) instead of } \\
\text { FC }\end{array}$ \\
\hline SCR, EGR, scrubber - $20 \%$ & same & same & same & same \\
\hline SCR, EGR, scrubber $+50 \%$ & same & same & same & same \\
\hline Fuel prices $-60 \%$ & same & same & same & same \\
\hline Fuel prices $+60 \%$ & same & $\begin{array}{l}\text { DF Gen-set } \\
\text { instead of FC }\end{array}$ & same & $\begin{array}{l}\text { DF Gen-set instead of } \\
\text { FC }\end{array}$ \\
\hline
\end{tabular}

From the results discussion, it is evident that the output values do not exhibit extreme variation within the tested ranges of the input parameters, especially for the best performing solutions for each objective. However, some variations are observed since the results are quite dependent on the input parameters. This denotes that the model is adequately 'sensitive' and therefore can capture the input parameters changes, which is desirable. Through the preceding analysis, it can be inferred that the uncertain parameters that may have the greatest impact on the optimal system configurations are the capital cost of the emerging technologies like the fuel cells and the carbon capture, the fuel prices and the variation of the main engine brake specific fuel consumption.

\subsection{Study limitations and final remarks} a high level, without considering the in-depth detail of the performance of the sub-systems; nonetheless, this choice accurately serves the ship energy system optimisation, since it is not a method to represent reality in all 
aspects. The systems simulation and evaluation is performed on steady-state conditions and the transient operating periods are disregarded, which is a common practice when the dynamic behaviour of the system is not important for the optimisation.

Although the multi-objective optimisation incorporates elitism, which prevents from losing good solutions once they are found, it is not always possible to provide the whole Pareto front since the algorithm stops when termination criteria are met and not necessarily when all the optimum solutions are obtained. However, it can be assumed that an accurate representation of the front is achieved as evidenced by comparing the case study application results with insights from the literature. Finally, the optimisation results depend on the input parameter values, which are considered deterministic and their stochasticity is not included in this study. A preliminary investigation of the input parameters variation impact on the optimisation results was performed. However, a detailed uncertainty analysis of the model is sought as a future work.

Only the main energy systems and technologies affecting those systems are considered in this method. In reality, additional energy systems components need to be selected, like ventilation and steering systems, that, however, do not have a great impact on the energy consumption of a tanker ship [18].

The economic investigation of the ship energy systems focuses on the life cycle cost, whereas the profitability of the technologies is not evaluated, as would be the case in real market conditions. This is because the method presented aims at identifying all the potential optimum configurations that can improve the performance of ship energy systems from a multi-objective perspective (environmental and economic objectives) and not just the profitable ones.

\section{Conclusions}

In this study, a method to optimise the ship energy systems synthesis with respect to environmental and economic objectives and with considerations of operational and regulatory requirements during the ship operational lifetime was presented. The method is innovative in addressing the integrated ship energy systems, managing the interactions among the subsystems by employing a systems engineering approach, thus avoiding sub-optimal solutions. An additional novelty is that environmental and economic objectives are integrally addressed in the optimisation, thus allowing the improvement of the environmental and economic sustainability of the ship systems. Lastly, the inclusion of the operational profiles and the degradation factors in the synthesis process leads in selecting the energy systems with consideration of performance based on the operational 
lifetime, which is a more realistic approach compared to the current established approach of using a design point.

The inclusion of the lifetime emissions on the optimisation process and not only focusing on cost offers a variety of alternative solutions. The visualisation of those alternatives with a Pareto front of dominant solutions allows the understanding of the trade-offs among the conflicting objectives. Furthermore, it offers the chance to the decision maker to be aware of all the potential optimum solutions and their trade-offs, beyond just being presented with one single solution, especially when making decisions that have an impact for 25 years. Understanding the 'range' of optimum solutions available can be useful, since a lot of uncertainty exists in the parameters, and the future environment is fluid, in terms of regulatory requirements.

- The traditional propulsion system with a diesel engine running with HFO and a scrubber and SCR in order to comply with the environmental regulations does not appear as one of the most sustainable solutions.

- The dual fuel engine technology that runs with natural gas has great advantages in reducing the emissions during the ship lifetime. Even though the additional costs for storage and feeding systems for natural gas have as a result the increase in the capital cost, it is still a solution that overall improves the sustainability of ship energy systems.

- Emerging technologies like fuel cells and carbon capture improve further the environmental impact of ship energy systems but this comes at a high cost in terms of the LCC of the ship systems. The results show that carbon capture is a prohibitive solution in real life context; however, the fuel cells can improve the energy systems sustainability.

- The inclusion of a shaft generator or a waste heat recovery technology has, as a result, an increase in the fuel consumption of the main engine but at the same time, a more efficient performance of the thermal boiler and auxiliary electric engine; therefore, they have a significant role to play in the improvement of the environmental and economic performance of ship energy systems.

- The combination of the SCR and EGR emission reduction technologies reduces drastically the NOx emissions, without deteriorating significantly the LCC, thus rendering this configuration a possible alternative, in order to overcome the future stringent NOx regulations. 
- The brake specific fuel consumption of the main engine, the fuel prices as well as the carbon capture system and fuel cells capital cost are identified as the most influential parameters on the selection of the optimum configurations.

In terms of academic contribution, it is the first study that introduces the environmental objective while performing multi-objective optimisation for the ship energy systems synthesis. The systems synthesis is based on an expected operational profile and not a specific design point as the traditional practice, thus extending the focus to the operational phase that has the greatest environmental and economic impact. Another contribution is that this is the first attempt to model the ship energy system synthesis problem as a multi-objective combinatorial optimisation problem. Moreover, in the multi-objective optimisation, multiple pollutants were considered, offering new insights of the trade-offs of energy systems selection. This approach can also be applied to other energy systems beyond ships, thus offering opportunities for academics to adapt this approach for applications in other sectors.

The developed method offers an extensive set of applications for the shipping industry, for ship-owners, designers as well as policy-makers. The method can assist practitioners in making more sustainable decisions that will allow mitigating the environmental impact whilst reducing the ship life cycle cost. It is a generic method and, when provided with accurate input data, can be applied to any merchant ship type. In addition, due to the modular nature of the model, it is possible to add more technologies and fuel choices by providing data for their performance. As a result, by including in the optimisation process current, emerging and future technologies, it is possible to obtain a better understanding of the future energy ship systems synthesis. However, the improvement in environmental performance cannot come cost-free and a win-win situation is elusive, thus, quantification of the cost needed for achieving a lower environmental impact is required. In other terms, determining the trade-offs between the environmental and economic aspects of ship systems sustainability is important, as managing of these trade-offs will lead to the most sustainable solution. The proposed method could be beneficial for ship-owners, as well as policy-makers, since it allows for obtaining a better understanding on the ability of existing ship energy systems to meet potential future stricter environmental regulations, as well as on the technologies needed to meet them, therefore providing guidance on the technology selection process. 


\begin{tabular}{|c|c|c|c|}
\hline \multicolumn{4}{|c|}{ Nomenclature } \\
\hline \multicolumn{2}{|c|}{ Abbreviations } & $\dot{m}_{f}$ & fuel amount mass flow $(\mathrm{kg} / \mathrm{h})$ \\
\hline CAPEX & Capital expenditures (€) & $N P$ & number of pollutants \\
\hline$C C$ & Carbon Capture system & $O$ & alternative technological solutions \\
\hline $\mathrm{CO}_{2}$ & Carbon dioxide & $p$ & pollutant \\
\hline$D$ & Diesel engine & $P$ & power $(k W)$ \\
\hline$D F$ & Dual Fuel engine & $P_{n}$ & nominal power $(k W)$ \\
\hline$D F G$ & Dual Fuel Generator & rpm & revolutions per minute ( $\mathrm{r} / \mathrm{min})$ \\
\hline$D G$ & Diesel Generator & $s f c$ & specific fuel consumption $(\mathrm{g} / \mathrm{kWh})$ \\
\hline$E C A$ & Emission Control Area & $s g c$ & specific gas consumption ( $\mathrm{g} / \mathrm{kWh})$ \\
\hline$E G R$ & Exhaust Gas Recirculation & spoc & specific pilot oil consumption $(\mathrm{g} / \mathrm{kWh})$ \\
\hline EU ETS & $\begin{array}{l}\text { European Emissions Trading } \\
\text { Scheme }\end{array}$ & $t_{y}$ & set of emission reduction technologies, $y=1 . . O_{e r}$ \\
\hline$F C$ & Fuel Cells & $t_{z}$ & set of energy efficiency technologies, $z=1 . . O_{e e}$ \\
\hline $\mathrm{HFO}$ & Heavy Fuel Oil & $Y$ & lifetime operation (years) \\
\hline$I M O$ & International Maritime Organisation & & \\
\hline$L C C$ & Life Cycle Cost $(€)$ & \multicolumn{2}{|c|}{ Greek symbol } \\
\hline$L H V$ & $\begin{array}{l}\text { Lower Heating Value of fuel } \\
(\mathrm{kJ} / \mathrm{kg})\end{array}$ & $\eta_{t h}$ & thermal boiler efficiency \\
\hline$L N G$ & Liquefied Natural Gas & & \\
\hline LSHFO & Low Sulphur heavy fuel oil & \multicolumn{2}{|c|}{ Subscripts } \\
\hline$M C R$ & Maximum Continuous Rating & $a e$ & auxiliary engine \\
\hline$M D O$ & Marine Diesel Oil & $e d$ & electric demand \\
\hline$M G O$ & Marine Gas Oil & $e p$ & electric power \\
\hline$N G$ & Natural Gas & me & main engine \\
\hline$N O x$ & Nitrogen oxides & $m p r$ & minimum power requirements \\
\hline$O \& M$ & Operational and Maintenance & $p$ & pollutant \\
\hline$O P E X$ & Operational expenditures $(€)$ & $p d$ & propulsion power demand \\
\hline$S C R$ & Selective Catalytic Reactor & $p p$ & propulsion power \\
\hline$S G$ & Shaft generator & ss & sub-system \\
\hline SOx & Sulphur oxides & $t d$ & thermal demand \\
\hline$W H R$ & Waste Heat Recovery & th & $\begin{array}{l}\text { thermal boiler } \\
\text { thermal power }\end{array}$ \\
\hline \multicolumn{4}{|c|}{ Parameters } \\
\hline$d f$ & deterioration factor of the engine (\%) & \multicolumn{2}{|c|}{ Independent decision variables } \\
\hline$C_{c}$ & capital cost factor $(€ / k W)$ & $b_{p, y}$ & $\begin{array}{l}\text { the binary variable that equals } 1 \text { if the emission reduction technology is selected } \\
\text { and } 0 \text { if it is not }\end{array}$ \\
\hline$C_{c o n}$ & consumables cost factor $(\epsilon)$ & $b_{z}$ & $\begin{array}{l}\text { the binary variable that equals } 1 \text { if the energy efficiency technology is selected } \\
\text { and } 0 \text { if it is not }\end{array}$ \\
\hline$c f$ & correction factor from ISO conditions & $e e$ & the vector that includes decision variables for the energy efficiency sub-system \\
\hline$C_{f}$ & fuel cost factor (€/ton) & er & the vector that includes decision variables for the emission reduction sub-system \\
\hline$C_{m}$ & maintenance cost factor $(€ / k W h)$ & es & the vector that includes decision variables for the electric sub-system \\
\hline$\Delta h$ & $\begin{array}{l}\text { specific enthalpy difference from } \\
\text { feedwater to saturated steam }(\mathrm{kJ} / \mathrm{kg})\end{array}$ & $N$ & the discrete variable for the number of sets \\
\hline E & annual emissions $(g)$ & $P_{n, m e}$ & the discrete variable for the nominal power of the main engine \\
\hline$E F_{e b}$ & emission factor energy based $(\mathrm{g} / \mathrm{kWh})$ & ps & the vector that includes decision variables for the propulsion sub-system \\
\hline$E F_{f b}$ & $\begin{array}{l}\text { emission factor fuel consumption } \\
\text { based ( } \mathrm{g} / \mathrm{g} \text { of fuel) }\end{array}$ & $t s$ & the vector that includes decision variables for the thermal sub-system \\
\hline ega & exhaust gas amount $(\mathrm{kg} / \mathrm{s})$ & & \\
\hline egt & exhaust gas temperature $\left({ }^{\circ} \mathrm{C}\right)$ & \multicolumn{2}{|c|}{ Decision Variables Sets } \\
\hline$h$ & $\begin{array}{l}\text { time per operational phase } \\
\text { (hours/year) }\end{array}$ & $f_{a e}$ & the set of fuel type alternatives for auxiliary engine $\left\{1 . . O_{f a e}\right\}$ \\
\hline$i$ & operational phases $i=1 . . I$ & $f_{m e}$ & the set of fuel type alternatives for main engine $\left\{1 . . O_{f m e}\right\}$ \\
\hline ir & interest rate $(\%)$ & $f_{t h}$ & the set of fuel type alternatives for thermal boiler $\left\{1 . . O_{f t h}\right\}$ \\
\hline$L$ & $\operatorname{load}(-)$ & $t_{a e}$ & the set of auxiliary electric alternative types $\left\{1 \ldots O_{a e}\right\}$ \\
\hline$\dot{m}_{s}$ & aturated steam mass flow $(\mathrm{kg} / \mathrm{h})$ & $t_{m e}$ & the set of main engine alternative types $\left\{1 \ldots O_{m e}\right\}$ \\
\hline & & $t_{t h}$ & the set of thermal boiler alternative types $\left\{1 \ldots O_{t h}\right\}$ \\
\hline
\end{tabular}

\section{Acknowledgments}

785 The research was supported by a University of Strathclyde Research Studentship. 
787 In this Appendix, the data points used for the regression as well as the curves derived by using the equations 788 provided in Tables 1 and 2 along with the constants provided in Tables 8 and 9 are presented. The performance 789 curves for a diesel engine are shown in Figure A.1, whereas the dual fuel engine performance curves in gas mode are illustrated in Figure A.2. Both engines have a nominal power $18760 \mathrm{~kW}$, which is close to the required power of the investigated ship main engine. The calculated R-squared values are also displayed in these figures, characterising the accuracy of the regression.
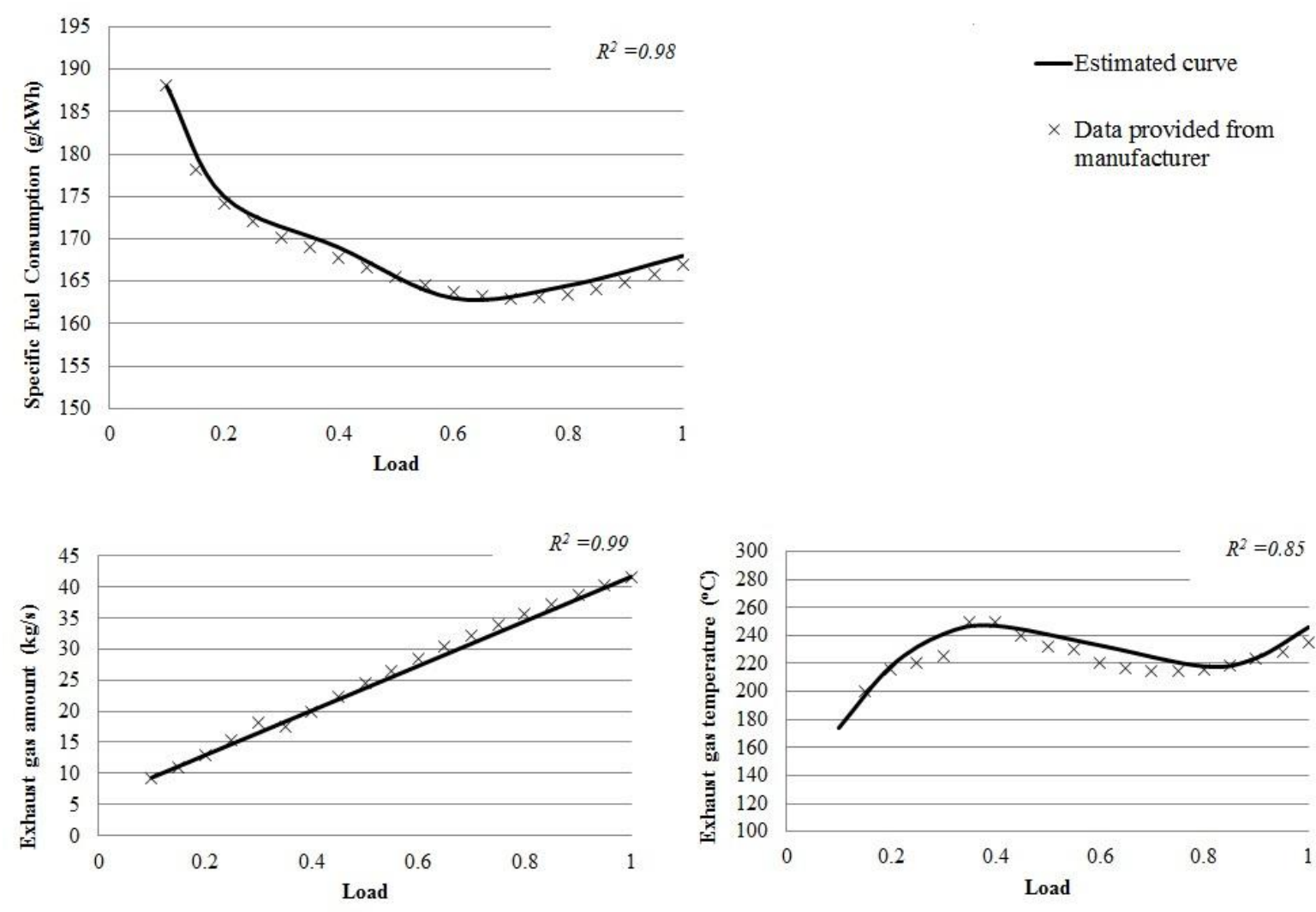

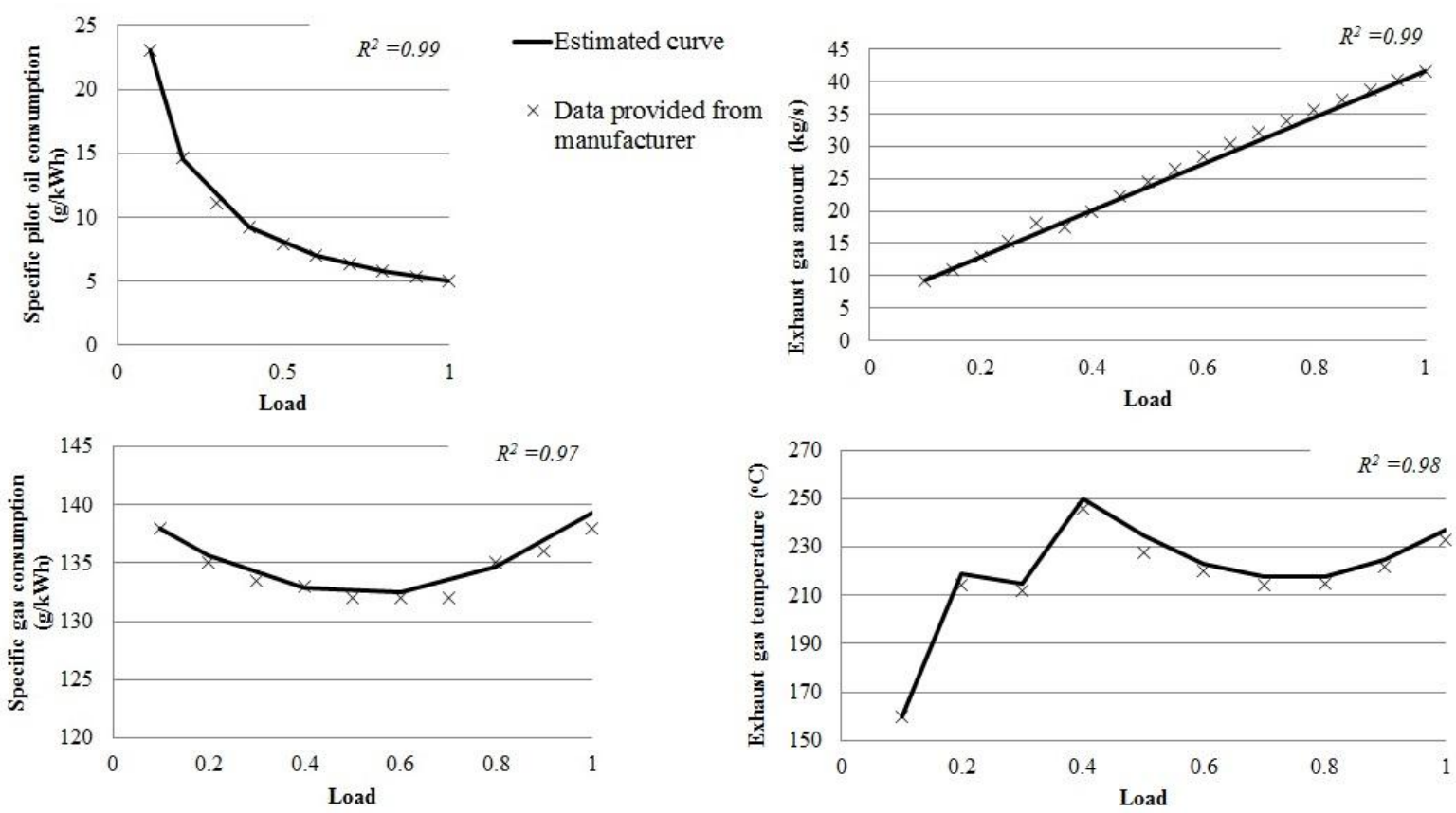

Figure A.2 Performance curves for dual fuel engines in gas mode (Nominal power $18760 \mathrm{~kW}$ )

\section{References}

[1] Sherbaz S, Maqsood A, Khan J. Machinery Options for Green Ship. J Eng Sci Technol Rev 2015;8:157-73.

[2] Fagerholt K, Psaraftis HN. On two speed optimization problems for ships that sail in and out of emission control areas. Transp Res Part D Transp Environ 2015;39:56-64. doi:10.1016/j.trd.2015.06.005.

[3] Cabezas-Basurko O, Mesbahi E, Moloney SR. Methodology for sustainability analysis of ships. Ships Offshore Struct 2008;3:1-11. doi:10.1080/17445300701673841.

[4] Mansouri SA, Lee H, Aluko O. Multi-objective decision support to enhance environmental sustainability in maritime shipping: A review and future directions. Transp Res Part E Logist Transp Rev 2015;78:3-18. doi:10.1016/j.tre.2015.01.012.

[5] Tillig F, Ringsberg J, Mao W, Ramne B. A generic energy systems model for efficient ship design and operation. Proc Inst Mech Eng Part M J Eng Marit Environ 2016;231:649-66. doi:10.1177/1475090216680672.

[6] Harrould-Kolieb E. Shipping Impacts on Climate: a Source with Solution. 2008.

[7] Eyring V, Isaksen, I., S. A, Berntsen T, Collins, W. J, Corbett, J. J, Endresen O, et al. Transport impacts on atmosphere and climate: Shipping. Atmos Environ 2010;44. doi:10.1016/j.atmosenv.2009.04.059.

811 [8] SA Risk -Sea. Air pollution from ships 2010:1-3.

[9] Carlton J, Aldwinkle J, Anderson J, Arcoumanis C, Balston D, Bardot A, et al. Future Ship Powering Options: Exploring alternative methods of ship propulsion. 2013. doi:ISBN: 989-1-909327-01-6.

$814 \quad$ [10] U.S. Energy Information Administration. Annual Energy Outlook. 2013.

[11] IMO. Annex 19-Resolution MEPC.203(62), Amendments to the annex of the protocol of 1997 to amend the international convention for the prevention of pollution from ships, 1973, as modified by the protocol of 1978 relating thereto. 2011.

[12] IMO. Annex 5, Resolution MEPC.245(66), Guidelines on the Method of Calculation of the Attained Energy Efficiency Design Index (EEDI) for New Ships. 2014.

[13] IMO. Annex 9, Resolution MEPC.213(63), 2012 Guidelines for the Development of a Ship Energy Efficiency Management Plan (SEEMP). 2012.

[14] Bazari Z, Longva T. Assessment of IMO Mandated Energy Efficiency Measures for International Shipping: Estimated CO2 Emissions Reduction from Introduction of Mandatory. 2011. doi:MEPC 63/INF.2.

[15] EU. Proposal for a Regulation of the European Parliament and of the Council on the Monitoring, Reporting and Verification of Carbon Dioxide Emissions From Maritime Transport and Amending Regulation (EU) No. 525/2013 - Political Agreement. 2014.

[16] Koesler S, Achtnicht M, Köhler J. Course set for a cap? A case study among ship operators on a maritime ETS. 
[17] Duić N, Guzović Z, Kafarov V, Klemes JJ, Mathiessen B vad, Yan J. Sustainable development of energy, water and environment systems. Appl Energy 2013;101:3-5. doi:10.1016/j.apenergy.2012.08.002.

[18] Baldi F, Johnson H, Gabrielii C, Andersson K. Energy and exergy analysis of ship energy systems - the case study of a chemical tanker. Int J Thermodyn 2015;18. doi:10.5541/ijot.5000070299.

[19] Bejan A, Tsatsaronis G, Moran M. Thermal \& design optimization. New York: John Wiley and Sons; 1996.

[20] Jiang L, Kronbak J, Christensen LP. The costs and benefits of sulphur reduction measures: Sulphur scrubbers versus marine gas oil. Transp Res Part D Transp Environ 2014;28:19-27. doi:10.1016/j.trd.2013.12.005.

[21] Schinas O, Stefanakos CN. Selecting technologies towards compliance with MARPOL Annex VI: The perspective of operators. Transp Res Part D Transp Environ 2014;28:28-40. doi:10.1016/j.trd.2013.12.006.

[22] Corbett J, Winebrake J, Green E. An assessment of technologies for reducing regional short-lived climate forcers emitted by ships with implications for Arctic shipping. Carbon Manag 2010;1:207-25. doi:10.4155/cmt.10.27.

[23] Balland O, Ove Erikstad S, Fagerholt K. Optimized selection of air emission controls for vessels. Marit Policy Manag 2012;39:387-400. doi:10.1080/03088839.2012.689877.

[24] Yang ZL, Zhang D, Caglayan O, Jenkinson ID, Bonsall S, Wang J, et al. Selection of techniques for reducing shipping NOx and SOx emissions. Transp Res Part D Transp Environ 2012;17:478-86. doi:10.1016/j.trd.2012.05.010.

[25] Wik C. Tier III technology development and its influence on ship installation and operation. CIMAC Congr. 2013, 2013.

[26] Balland O, Erikstad SO, Fagerholt K, Wallace SW. Planning vessel air emission regulations compliance under uncertainty. J Mar Sci Technol 2013;18:349-57. doi:10.1007/s00773-013-0212-7.

[27] Lloyd's Register. Your options for emissions compliance 2015:60.

[28] Alvik S, Eide MS, Endresen O, Hoffmann P, Longva T. Pathways to Low Carbon Shipping - Abatement potential towards 2030. 2009.

[29] Singh DV, Pedersen E. A review of waste heat recovery technologies for maritime applications. Energy Convers Manag 2016;111:315-28. doi:10.1016/j.enconman.2015.12.073.

[30] Theotokatos G, Livanos G. Techno-economical analysis of single pressure exhaust gas waste heat recovery systems in marine propulsion plants. Proc Inst Mech Eng Part M J Eng Marit Environ 2013;227:83-97. doi:10.1177/1475090212457894.

[31] Grljušić M, Medica V, Radica G. Calculation of efficiencies of a ship power plant operating with waste heat recovery through combined heat and power production. Energies 2015;8:4273-99. doi:10.3390/en8054273.

[32] Baldi F, Gabrielii C. A feasibility analysis of waste heat recovery systems for marine applications. Energy 2015;80:654-65. doi:10.1016/j.energy.2014.12.020.

[33] Kalikatzarakis M, Frangopoulos CA. Multi-criteria selection and thermo-economic optimization of Organic Rankine Cycle system for a marine application. Int J Thermodyn 2015;18:133. doi:10.5541/ijot.5000075305.

[34] Shu G, Liu P, Tian H, Wang X, Jing D. Operational profile based thermal-economic analysis on an Organic Rankine cycle using for harvesting marine engine's exhaust waste heat. Energy Convers Manag 2017;146:107-23. doi:10.1016/j.enconman.2017.04.099.

[35] Yang MH. Thermal and economic analyses of a compact waste heat recovering system for the marine diesel engine using transcritical Rankine cycle. Energy Convers Manag 2015;106:1082-96. doi:10.1016/j.enconman.2015.10.050.

[36] Mondejar ME, Ahlgren F, Thern M, Genrup M. Quasi-steady state simulation of an organic Rankine cycle for waste heat recovery in a passenger vessel. Appl Energy 2017;185:1324-35. doi:10.1016/j.apenergy.2016.03.024.

[37] Kyriakidis F, Sørensen K, Singh S, Condra T. Modeling and optimization of integrated exhaust gas recirculation and multi-stage waste heat recovery in marine engines. Energy Convers Manag 2017;151:286-95. doi:10.1016/j.enconman.2017.09.004.

[38] Soffiato M, Frangopoulos CA, Manente G, Rech S, Lazzaretto A. Design optimization of ORC systems for waste heat recovery on board a LNG carrier. Energy Convers Manag 2015;92:523-34. doi:10.1016/j.enconman.2014.12.085.

[39] Larsen U, Pierobon L, Haglind F, Gabrielii C. Design and optimisation of organic Rankine cycles for waste heat recovery in marine applications using the principles of natural selection. Energy 2013;55:803-12. doi:10.1016/j.energy.2013.03.021.

[40] Burel F, Taccani R, Zuliani N. Improving sustainability of maritime transport through utilization of Liquefied Natural Gas (LNG) for propulsion. Energy 2013;57:412-20. doi:10.1016/j.energy.2013.05.002.

[41] Mavrelos C, Theotokatos G. Numerical investigation of a premixed combustion large marine two-stroke dual fuel engine for optimising engine settings via parametric runs. Energy Convers Manag 2018;160:48-59. doi:10.1016/j.enconman.2017.12.097.

[42] Mrzljak V, Poljak I, Mrakovčić T. Energy and exergy analysis of the turbo-generators and steam turbine for the 
[43] Tzortzis GJ, Frangopoulos CA. Dynamic optimization of synthesis, design and operation of marine energy systems. Proc Inst Mech Eng Part M J Eng Marit Environ 2018. doi:10.1177/1475090217749370.

[44] Livanos GA, Theotokatos G, Pagonis D-N. Techno-economic investigation of alternative propulsion plants for Ferries and RoRo ships. Energy Convers Manag 2014;79:640-51. doi:10.1016/j.enconman.2013.12.050.

[45] Baldi F, Bengtsson S, Andersson K. The influence of propulsion system design on the carbon footprint of different marine fuels. Low Carbon Shipp Conf 2013:1-12.

[46] Dimopoulos GG, Kougioufas A V., Frangopoulos CA. Synthesis, design and operation optimization of a marine energy system. Energy 2008;33:180-8. doi:10.1016/j.energy.2007.09.004.

[47] Balland O, Erikstad SO, Fagerholt K. Concurrent design of vessel machinery system and air emission controls to meet future air emissions regulations. Ocean Eng 2014;84:283-92. doi:10.1016/j.oceaneng.2014.04.013.

[48] Sciberras EA, Norman RA. Multi-objective design of a hybrid propulsion system for marine vessels. IET Electr Syst Transp 2012;2:148. doi:10.1049/iet-est.2011.0011.

[49] Baldi F, Ahlgren F, Melino F, Gabrielii C, Andersson K. Optimal load allocation of complex ship power plants. Energy Convers Manag 2016;124:344-56. doi:10.1016/j.enconman.2016.07.009.

[50] Solem S, Fagerholt K, Erikstad SO, Patricksson Ø. Optimization of diesel electric machinery system configuration in conceptual ship design. J Mar Sci Technol 2015:406-16. doi:10.1007/s00773-015-0307-4.

[51] Biert L van, Godjevac M, Visser K, Aravind P V. A review of fuel cell systems for maritime applications. J Power Sources 2016;327:345-64. doi:10.1016/j.jpowsour.2016.07.007.

[52] Alkaner S, Zhou P. A comparative study on life cycle analysis of molten carbon fuel cells and diesel engines for marine application. J Power Sources 2006;158:188-99. doi:10.1016/j.jpowsour.2005.07.076.

[53] Dimopoulos GG, Stefanatos IC, Kakalis NMP. Exergy analysis and optimisation of a marine molten carbonate fuel cell system in simple and combined cycle configuration. Energy Convers Manag 2016;107:10-21. doi:10.1016/j.enconman.2015.09.007.

[54] Baldi F, Gabrielii C, Melino F, Bianchi M. A preliminary study on the application of thermal storage to merchant ships. Proc. Int. Conf. Appl. Energy, vol. 75, Elsevier B.V.; 2015, p. 2169-74. doi:10.1016/j.egypro.2015.07.364.

[55] Lan H, Wen S, Hong YY, Yu DC, Zhang L. Optimal sizing of hybrid PV/diesel/battery in ship power system. Appl Energy 2015;158:26-34. doi:10.1016/j.apenergy.2015.08.031.

[56] Atkinson GM. Analysis of marine solar power trials on Blue Star Delos. J Mar Eng Technol 2016;15:115-23. doi:10.1080/20464177.2016.1246907.

[57] Gong J, You F. Sustainable design and synthesis of energy systems. Curr Opin Chem Eng 2015;10:77-86. doi:10.1016/j.coche.2015.09.001.

[58] Santoyo-Castelazo E, Azapagic A. Sustainability assessment of energy systems: Integrating environmental, economic and social aspects. J Clean Prod 2014;80:119-38. doi:10.1016/j.jclepro.2014.05.061.

[59] Baldi F. Modelling, analysis and optimisation of ship energy systems PhD Thesis. Chalmers University of Technology, 2016.

[60] Stasinopoulos P, Smith MH, Hargroves K, Desha C. Whole System Design: An integrated approach to sustainable engineering design. London, UK: Earthscan; 2009.

[61] Banks C, Turan O, Incecik A, Theotokatos G, Izkan S, Shewell C, et al. Understanding Ship Operating Profiles with an Aim to Improve Energy Efficient Ship Operations. Low Carbon Shipp. Conf., 2013, p. 1-11.

[62] Coraddu A, Figari M, Savio S. Numerical investigation on ship energy efficiency by Monte Carlo simulation. Proc Inst Mech Eng Part M J Eng Marit Environ 2014;228:220-34. doi:10.1177/1475090214524184.

[63] Dimopoulos GG, Kakalis NMP. An integrated modelling framework for the design , operation and control of marine energy systems. CIMAC Congr 20102010.

[64] Ahlgren F, Mondejar ME, Genrup M, Thern M. Waste Heat Recovery in a Cruise Vessel in the Baltic Sea by Using an Organic Rankine Cycle: A Case Study. J Eng Gas Turbines Power 2015;138:11702. doi:10.1115/1.4031145.

[65] IMO. Annex VI-Regulations for the prevention of Air Pollution from Ships. Sulphur Oxides (SOx)-Regulation 14 2005.

[66] IMO. Annex VI, Regulations for the prevention of Air Pollution from Ships. Nitrogen Oxides (NOx), Regulation 13 2005.

[67] IMO. Annex 16, Resolution MEPC. 232(65)-2013 Interim guidelines for determining minimum propulsion power to maintain the manoeuvrability of ships in adverse conditions. vol. 232. 2013.

[68] Blanchard B, Fabrycky W. System engineering and analysis. 5th ed. US: Pearson Prentice Hall; 2014.

[69] Gaspar HM, Rhodes DH, Ross AM, Erikstad SO. Addressing complexity aspects in conceptual ship design: A systems engineering approach. J Sh Prod Des 2012;28:145-59. doi:10.5957/JSPD.28.4.120015.

[70] Man Diesel \& Turbo. CEAS Engine Calculations. 2017.

[71] SNAME. Marine Diesel Power Plant Practises, T\&R Bulletin 3-49. 1990. 
[72] Wärtsilä. Wärtsilä Environmental Product Guide. Finland: 2015.

945 [73] Zhou P, Wang H. Carbon capture and storage - Solidification and storage of carbon dioxide captured on ships.

Ocean Eng 2014;91:172-80. doi:10.1016/j.oceaneng.2014.09.006.

[74] MAN Diesel \& Turbo. MAN Four-Stroke Propulsion Engines. 2015.

948 [75] Wärtsilä. Dual Fuel engines- Wärtsilä. 2015.

[76] Basurko OC, Mesbahi E. Methodology for the sustainability assessment of marine technologies. J Clean Prod 2014;68:155-64. doi:10.1016/j.jclepro.2012.01.022.

[77] Utne IB. Life cycle cost (LCC) as a tool for improving sustainability in the Norwegian fishing fleet. J Clean Prod 2009;17:335-44. doi:10.1016/j.jclepro.2008.08.009.

[78] Gaspar HM, Balland O, Aspen DM, Ross AM, Erikstad SO. Assessing air emissions for uncertain lifecycle scenarios via responsive systems comparison method. Proc IMechE Part M J Eng Marit Environ 2014;229:1-15. doi:10.1177/1475090214522218.

[79] Fet AM, Aspen DM, Ellingsen H. Systems engineering as a holistic approach to life cycle designs. Ocean Eng 2013;62:1-9. doi:10.1016/j.oceaneng.2013.01.003.

[80] Chatzinikolaou SD, Ventikos NP. Critical Analysis of Air Emissions from Ships: Lifecycle Thinking and Results. Green Transp. Logist. Quest Win-Win Solut., 2015. doi:10.1007/978-3-319-17175-3.

[81] Moreno-Gutiérrez J, Calderay F, Saborido N, Boile M, Rodríguez Valero R, Durán-Grados V. Methodologies for estimating shipping emissions and energy consumption: A comparative analysis of current methods. Energy 2015;86:603-16. doi:10.1016/j.energy.2015.04.083.

[82] Andersson K, Brynolf S, Lindgren FJ, Wilewska M. Shipping and the Environment: Improving Environmental Performance in Marine Transportation. 1st ed. Berlin: Springer; 2016. doi:10.1007/978-3-662-49045-7.

[83] Chatzinikolaou S, Ventikos NP. Applications of Life Cycle Assessment in Shipping Industry, 2014. doi:10.5593/SGEM2014/B42/S19.038.

[84] Trozzi C, Consulting T, Gregorio V, Curbastro R, Roma I. Emission estimate methodology for maritime navigation. 2006.

[85] Entec. Ship Emissions Final Report - Quantification of Ship Emissions. Sh Emiss Final Reeport 2002:3-48.

[86] Murphy A, Landamore M, Pazouki K, Gibson M. Modelling ship emission factors and emission indices. Low Carbon Shipp Conf 2013:18.

[87] Smith TWP, Jalkanen JP, Anderson BA, Corbett JJ, Faber J, Hanayama S, et al. Third IMO Greenhouse Gas Study 2014. Int Marit Organ 2014:327.

[88] Cichowicz J, Theotokatos G, Vassalos D. Dynamic energy modelling for ship life-cycle performance assessment. Ocean Eng 2015;110:1-13. doi:10.1016/j.oceaneng.2015.05.041.

[89] Coello Coello CA, Dhaenens C, Jourdan L. Multi-objective combinatorial optimization: Problematic and context. Adv Multi-Objective Nat Inspired Comput 2010;272:1-21. doi:10.1007/978-3-642-11218-8_1.

[90] Wang JJ, Jing YY, Zhang CF, Zhao JH. Review on multi-criteria decision analysis aid in sustainable energy decision-making. Renew Sustain Energy Rev 2009;13:2263-78. doi:10.1016/j.rser.2009.06.021.

[91] Quariguasi Frota Neto J, Walther G, Bloemhof J, van Nunen JAEE, Spengler T. A methodology for assessing ecoefficiency in logistics networks. Eur J Oper Res 2009;193:670-82. doi:10.1016/j.ejor.2007.06.056.

[92] Pelet X, Favrat D, Leyland G. Multiobjective optimisation of integrated energy systems for remote communities considering economics and CO2 emissions. Int J Therm Sci 2005;44:1180-9. doi:10.1016/j.ijthermalsci.2005.09.006.

[93] Rodrigues S, Bauer P, Bosman PAN. Multi-objective optimization of wind farm layouts - Complexity, constraint handling and scalability. Renew Sustain Energy Rev 2016;65:587-609. doi:10.1016/j.rser.2016.07.021.

[94] Deb K, Agrawal S, Pratap A, Meyarivan T. A Fast Elitist Non-dominated Sorting Genetic Algorithm for Multiobjective Optimization: \{NSGA\}-II. Proc 6th Int Conf Parallel Probl Solving from Nat 2000.

[95] Yousefi M, Kim JH, Hooshyar D, Yousefi M, Sahari KSM, Ahmad RB. A practical multi-objective design approach for optimum exhaust heat recovery from hybrid stand-alone PV-diesel power systems. Energy Convers Manag 2017;142:559-73. doi:10.1016/j.enconman.2017.03.031.

[96] Sheikholeslami M, Ganji DD. Heat transfer improvement in a double pipe heat exchanger by means of perforated turbulators. Energy Convers Manag 2016;127:112-23. doi:10.1016/j.enconman.2016.08.090.

[97] Ko M, Kim Y, Chung M, Jeon H. Multi-Objective Optimization Design for a Hybrid Energy System Using the Genetic Algorithm. Energies 2015;8:2924-49. doi:10.3390/en8042924.

[98] Wang J, Yan Z, Wang M, Li M, Dai Y. Multi-objective optimization of an organic Rankine cycle (ORC) for low grade waste heat recovery using evolutionary algorithm. Energy Convers Manag 2013;71:146-58. doi:10.1016/j.enconman.2013.03.028.

[99] Turkmen BS, Turan O. A new integrated multi-objective optimisation algorithm and its application to ship design. Ships Offshore Struct 2007;2:21-37. doi:10.1533/saos.2006.0143.

1001

[100] Lee J, Shin S, Kim S. An optimal design of marine systems based on neuro- response surface method. Int J Nav 
[101] Jain V, Sachdeva G. Energy, exergy, economic (3E) analyses and multi-objective optimization of vapor absorption heat transformer using NSGA-II technique. Energy Convers Manag 2017;148:1096-113. doi:10.1016/j.enconman.2017.06.055.

[102] Deb M, Debbarma B, Majumder A, Banerjee R. Performance -emission optimization of a diesel-hydrogen dual fuel operation: A NSGA II coupled TOPSIS MADM approach. Energy 2016;117:281-90. doi:10.1016/j.energy.2016.10.088.

[103] Abul'Wafa AR. Optimization of economic/emission load dispatch for hybrid generating systems using controlled Elitist NSGA-II. Electr Power Syst Res 2013;105:142-51. doi:10.1016/j.epsr.2013.07.006.

[104] Man Diesel \& Turbo. Basic Principles of Ship Propulsion. 2011.

[105] Wik C. Low emission engine technologies for future Tier 3 legislations- Options and case studies. J Shipp Trade 2016:1-34. doi:10.1186/s41072-016-0009-z.

[106] Eurostat. Producer price index, Total EU-28 2017. http://ec.europa.eu/eurostat/statisticsexplained/index.php/Industrial_producer_price_index_overview.

[107] Luo X, Wang M. Study of solvent-based carbon capture for cargo ships through process modelling and simulation. Appl Energy 2017;195:402-13. doi:10.1016/j.apenergy.2017.03.027.

[108] Smith DJ. Design and Operational Changes are Reducing the Cost of Reciprocating Engine Maintenance. Power Eng., 2004.

[109] Tzannatos E, Papadimitriou S, Koliousis I. A Techno-Economic Analysis of Oil vs. Natural Gas Operation for Greek Island Ferries. Int J Sustain Transp 2015;9:272-81. doi:10.1080/15568318.2013.767397.

[110] Clausen NB. Tier III NO x Emission Reduction Technologies EGR and SCR. 2015.

[111] EIA. Updated Capital Cost Estimates for Utility Scale Electricity Generating Plants. 2013. doi:10.2172/784669.

[112] Vanwortswinkel L, Nijs W. Industrial Combustion Boilers. 2010. doi:10.1201/EBK1420085280.

[113] Lövblad, G., Fridell E. Experiences from use of some techniques to reduce emissions from ships 2006.

[114] Tremuli P. Developments and Perspectives of Marine Engines. Clean Combust. Greenh. Gases, 2008.

[115] IRENA. Renewable energy technologies: cost analysis series: Wind Power. vol. 1. 2012. doi:10.1016/B978-0-08098330-1.00011-9.

[116] Listewnik J. Feasibility Analysis Of Shaft Generators Application For Optimum Electric Power Generation At Sea In New Built Ships. WIT Trans Built Environ 1995;12:407-15. doi:10.2495/MT950471.

[117] Dimopoulos G, Kougioufas A, Frangopoulos C. Synthesis , design and operation optimization of a marine energy system. National Technical University of Athens, 2008. doi:10.1016/j.energy.2007.09.004.

[118] MAN Diesel. ME-GI Dual Fuel MAN B \& W Engines 2013:1-32.

[119] U.S. Environmental Protection Agency. Emissions Factors. vol. I. 1999.

[120] Welaya YMA, El Gohary MM, Ammar NR. A comparison between fuel cells and other alternatives for marine electric power generation. Int J Nav Archit Ocean Eng 2011;3:141-9. doi:10.3744/JNAOE.2011.3.2.141.

[121] Wang H, Zhou P, Wang Z. Reviews on current carbon emission reduction technologies and projects and their feasibilities on ships. J Mar Sci Appl 2017;16:129-36. doi:10.1007/s11804-017-1413-y.

[122] Morris MD. Factorial Sampling Plans for Prelim inary Computational Experiments. Technometrics 1991;33:16174.

[123] Uusitalo L, Lehikoinen A, Helle I, Myrberg K. An overview of methods to evaluate uncertainty of deterministic models in decision support. Environ Model Softw 2015;63:24-31. doi:10.1016/j.envsoft.2014.09.017. 